\title{
Steps towards a mechanistic model of global soil nitric oxide emissions: implementation and space based-constraints
}

\author{
R. C. Hudman ${ }^{1}$, N. E. Moore ${ }^{2,}$, A. K. Mebust ${ }^{1}$, R. V. Martin ${ }^{2,3}$, A. R. Russell ${ }^{1}$, L. C. Valin ${ }^{1}$, and R. C. Cohen ${ }^{1,4}$ \\ ${ }^{1}$ Department of Chemistry, University of California at Berkeley, Berkeley, CA, USA \\ ${ }^{2}$ Department of Physics and Atmospheric Science, Dalhousie University, Halifax, Nova Scotia, Canada \\ ${ }^{3}$ Harvard-Smithsonian Center for Astrophysics, Cambridge, MA, USA \\ ${ }^{4}$ Department of Earth and Planetary Sciences, University of California at Berkeley, Berkeley, CA, USA \\ * now at: Department of Municipal Services, City of Summerside, Summerside, Prince Edward Island, Canada
}

Correspondence to: R. C. Cohen (rccohen@ berkeley.edu)

Received: 9 January 2012 - Published in Atmos. Chem. Phys. Discuss.: 1 February 2012

Revised: 9 August 2012 - Accepted: 16 August 2012 - Published: 30 August 2012

\begin{abstract}
Soils have been identified as a major source $(\sim 15 \%)$ of global nitrogen oxide $\left(\mathrm{NO}_{\mathrm{x}}\right)$ emissions. Parameterizations of soil $\mathrm{NO}_{\mathrm{x}}$ emissions $\left(S_{\mathrm{NO}_{\mathrm{x}}}\right)$ commonly used in the current generation of chemical transport models were designed to capture mean seasonal behaviour. These parameterizations do not, however, respond quantitatively to the meteorological triggers that are observed to result in pulsed $S_{\mathrm{NO}_{\mathrm{x}}}$. Here we present a new parameterization of $S_{\mathrm{NO}_{\mathrm{x}}} \mathrm{im}$ plemented within a global chemical transport model (GEOSChem). The parameterization represents available nitrogen $(\mathrm{N})$ in soils using biome specific emission factors, online wet- and dry-deposition of $\mathrm{N}$, and fertilizer and manure $\mathrm{N}$ derived from a spatially explicit dataset, distributed using seasonality derived from data obtained by the Moderate Resolution Imaging Spectrometer. Moreover, it represents the functional form of emissions derived from point measurements and ecosystem scale experiments including pulsing following soil wetting by rain or irrigation, and emissions that are a smooth function of soil moisture as well as temperature between 0 and $30^{\circ} \mathrm{C}$. This parameterization yields global above-soil $S_{\mathrm{NO}_{\mathrm{x}}}$ of $10.7 \mathrm{Tg} \mathrm{N} \mathrm{yr}^{-1}$, including $1.8 \mathrm{Tg} \mathrm{N} \mathrm{yr}^{-1}$ from fertilizer $\mathrm{N}$ input (1.5\% of applied $\mathrm{N}$ ) and $0.5 \mathrm{Tg} \mathrm{N} \mathrm{yr}^{-1}$ from atmospheric $\mathrm{N}$ deposition. Over the United States (US) Great Plains region, $S_{\mathrm{NO}_{\mathrm{x}}}$ are predicted to comprise $15-40 \%$ of the tropospheric $\mathrm{NO}_{2}$ column and increase column variability by a factor of 2-4 during the summer months due to chemical fertilizer application and warm temperatures. $S_{\mathrm{NO}_{\mathrm{x}}}$ enhancements of $50-80 \%$ of the simulated $\mathrm{NO}_{2}$ column are predicted over the African Sahel during the monsoon onset
\end{abstract}

(April-June). In this region the day-to-day variability of column $\mathrm{NO}_{2}$ is increased by a factor of 5 due to pulsed-N emissions. We evaluate the model by comparison with observations of $\mathrm{NO}_{2}$ column density from the Ozone Monitoring Instrument (OMI). We find that the model is able to reproduce the observed interannual variability of $\mathrm{NO}_{2}$ (induced by pulsed-N emissions) over the US Great Plains. We also show that the OMI mean (median) $\mathrm{NO}_{2}$ observed during the overpass following first rainfall over the Sahel is $49 \%(23 \%)$ higher than in the five days preceding. The measured $\mathrm{NO}_{2}$ on the day after rainfall is still $23 \%$ (5\%) higher, providing a direct measure of the pulse's decay time of 1-2 days. This is consistent with the pulsing representation used in our parameterization and much shorter than 5-14 day pulse decay length used in current models.

\section{Introduction}

Nitric oxide emissions from microbial processes in soils represent $\sim 15 \%$ of the modern global atmospheric $\mathrm{NO}_{\mathrm{x}}(\equiv \mathrm{NO}$ $\left.+\mathrm{NO}_{2}\right)$ source $(\sim 50 \%$ in preindustrial times) and are a major contribution to the $\mathrm{NO}_{\mathrm{x}}$ budget outside of cities (Holland et al., 1999). Atmospheric $\mathrm{NO}_{\mathrm{x}}$ is thus coupled to the Earth's nitrogen cycle through a complex web of interactions involving soil microbial activity, soil nitrogen $(\mathrm{N})$ content and anthropogenic fertilizer rates (Galloway et al., 2004; Phoenix et al., 2006). Understanding and modeling these interactions is essential to predict atmospheric composition and 
to understand the direct and indirect effects of soil $\mathrm{NO}_{\mathrm{x}}$ emissions $\left(S_{\mathrm{NO}_{\mathrm{x}}}\right)$ on ozone, aerosol, and climate (Dentener and Crutzen, 1993; Andreae and Crutzen, 1997; Martin et al., 2003; Steinkamp et al., 2009).

While the outline of the biogeochemistry of $S_{\mathrm{NO}_{\mathrm{x}}}$ has been well established, identifying details of the mechanisms and strategies for scaling from laboratory and point measurements in the field to ecosystem scales or to the larger scales of regional and global models remains challenging and both poorly evaluated and verified. Measurements using soil chambers in the field and laboratory experiments show that $S_{\mathrm{NO}_{\mathrm{x}}}$ vary greatly with climate and edaphic conditions, but are most strongly correlated with $\mathrm{N}$-availability, temperature and soil moisture, making $S_{\mathrm{NO}_{\mathrm{x}}}$ dependent on regional temperature and precipitation patterns and fertilizer management practices (e.g., Williams and Fehsenfeld, 1991; Bouwman et al., 2002; Meixner and Yang, 2006; Hudman et al., 2010). However, the advent of space-based measurement capabilities for $\mathrm{NO}_{2}$ column densities provides a new opportunity to observe $S_{\mathrm{NO}_{\mathrm{x}}}$ over larger domains and to capture statistics of their variability in space and time as the emissions respond to meteorological drivers and to anthropogenic fertilizer (van $\operatorname{der}$ A, 2008).

Here, we present an updated global $S_{\mathrm{NO}_{\mathrm{x}}}$ parameterization, the Berkeley-Dalhousie Soil $\mathrm{NO}_{\mathrm{x}}$ Parameterization (BDSNP), which includes a more physical representation of the key processes derived from field measurements than did previous parameterizations: (1) soil moisture and temperature dependence are decoupled allowing for a continuum of $S_{\mathrm{NO}_{\mathrm{x}}}$ response rather than discrete wet or dry states, and (2) pulsing length and strength is modified to depend on soil moisture history rather than precipitation amounts. Additionally, we update fertilizer-maps and treatments of $S_{\mathrm{NO}_{\mathrm{x}}}$ : (a) $\mathrm{N}$ fertilizer emissions are updated using the latest gridded inventories for chemical fertilizers and manure, (b) growing season start and end dates derived from data obtained by the Moderate Resolution Imaging Spectrometer (MODIS) are used to account for timing and distribution of $\mathrm{N}$ fertilizer, (c) $\mathrm{N}$ fertilizer is now incorporated into a parameter representing the standing pool of $\mathrm{N}$ in the soils and otherwise treated identically to the natural pool of $\mathrm{N}$, responding to temperature and soil moisture and resulting in pulsed emissions, and (d) wet and dry deposition of ammonia $\left(\mathrm{NH}_{3}\right)$, ammonium $\left(\mathrm{NH}_{4}^{+}\right)$, nitric acid $\left(\mathrm{HNO}_{3}\right)$, nitrate $\left(\mathrm{NO}_{3}^{-}\right)$, nitrogen dioxide $\left(\mathrm{NO}_{2}\right)$, and peroxyacetyl nitrate (PAN) are included as terms that affect the soil N pool and thus $S_{\mathrm{NO}_{\mathrm{x}}}$. This more mechanistic approach improves the time resolution of modeled soil emissions, implying that the model can better reproduce daily variability and allow the study of important processes such as daily ozone response and the atmospheric lifetime of the emitted $\mathrm{NO}_{\mathrm{x}}$. Both quantities are strongly non-linear functions of $\mathrm{NO}_{\mathrm{x}}$ and as a result will be systematically biased if the temporal patterns of pulsed emissions are represented as a continuum emission on a month-long or seasonal time scale. After describing this new parameterization and its im- plementation in the GEOS-Chem chemical transport model (CTM), we describe comparisons of the predictions to those made with recent implementations of a model by Yienger and Levy (1995) (YL95) and some initial attempts at evaluation of the BDSNP using satellite observations. Descriptions of the model setup and satellite product retrievals can be found in the Appendices A and B, respectively.

\section{Prior parameterizations}

$S_{\mathrm{NO}_{\mathrm{x}}}$ have been estimated on regional and global scales using process-based models (Potter et al., 1996; Parton et al., 2001), empirical models (Yienger and Levy, 1995; Yan et al., 2005; Delon et al., 2007; Steinkamp and Lawrence, 2011), and by scaling field observations (Davidson and Kingerlee, 1997) with global above-canopy estimates ranging from 4.7$13 \mathrm{Tg} \mathrm{N} \mathrm{yr}^{-1}$ (Table 1). Most process-based gaseous N models use an implementation of the conceptual hole-in-the pipe model of Firestone and Davidson (1989), where N-emission $\left(\mathrm{N}_{2} \mathrm{O}, \mathrm{NO}, \mathrm{N}_{2}\right)$ is proportional to nitrification/denitrification rates, soil gas diffusivity, and other edaphic conditions (Potter et al., 1996; Parton et al., 2001; Butterbach-Bahl et al., 2009). For example, the NASA-CASA model (Potter et al., 1996) assumes that a fixed $2 \%$ of mineralized $\mathrm{N}$ is emitted as some form of $\mathrm{NO}: \mathrm{N}_{2} \mathrm{O}: \mathrm{N}_{2}$ depending on soil moisture availability. To account for the pulsing of dry soils, the DAYCENT model (Parton et al., 2001) uses a parameterization based on precipitation history (Yienger and Levy, 1995), while the CASA and the DeNitrification-DeComposition (DNDC; Butterbach-Bahl et al., 2009) models do not explicitly specify pulsed emissions, although the process-based DNDC model may reproduce these pulses. Pulsed emissions have been shown to contribute up to $22 \%$ of annual emissions on a regional scale (Davidson, 1992b) and satellite observations (including those described below) suggest the fraction might be larger in many locations (e.g., Bertram et al., 2005; Hudman et al., 2010).

\section{YL95 and its recent implementations}

At present, $S_{\mathrm{NO}_{\mathrm{x}}}$ processes are represented in most CTMs using various implementations of the YL95 empirical scheme, which computes emissions as a function of temperature, precipitation, fertilizer application, vegetation type, and canopycover (e.g., Bey et al., 2001; Emmons et al., 2010). Regional comparisons with surface and satellite observations, however, suggest the standard YL95 scheme results in emissions that are a factor of 2-4 too low (e.g., Jaeglé et al., 2005; Wang et al., 2007; Boersma et al., 2008; Zhao and Wang, 2009; Steinkamp and Lawrence, 2011; Lin, 2012). In principle, it is possible to create a set of regionally corrected parameters, as Bertram et al. (2005) did for a single emission episode in the northern Great Plains of the United States. Current CTMs, however, contain much more information about the 
Table 1. Published estimates of global soil $\mathrm{NO}_{\mathrm{x}}$ emissions $\left(S_{\mathrm{NO}_{\mathrm{x}}}, \mathrm{Tg} \mathrm{N} \mathrm{yr}^{-1}\right)$.

\begin{tabular}{|c|c|c|c|c|c|}
\hline Reference & Fert $^{1}$ & $\mathrm{~N} \operatorname{Dep}^{2}$ & $\begin{array}{l}\text { Above- } \\
\text { Soil }^{3}\end{array}$ & $\begin{array}{l}\text { Above- } \\
\text { Canopy }\end{array}$ & Description \\
\hline $\begin{array}{l}\text { Galbally and } \\
\text { Roy (1978) }\end{array}$ & & & 10 & & $\begin{array}{l}\text { Average of } S_{\mathrm{NO}_{\mathrm{x}}} \text { from } 3 \text { sites }\left(3 \mathrm{ng} \mathrm{N} \mathrm{m}^{-2} \mathrm{~s}^{-1}\right) \text { is multiplied } \\
\text { by global land surface area. }\end{array}$ \\
\hline Muller (1992) & & & 6.6 & 4.7 & $\begin{array}{l}\text { A land-use map is used in combination with the following re- } \\
\text { lationships: (a) Exponential } T \text { dependence from Williams et al. } \\
(1987)^{5} \text { for all soils except tropical forests, (b) Fertilized fields } \\
\times 3 \text { and (c) Tropical Forests } S_{\mathrm{NO}_{\mathrm{x}}} \sim 1 / \text { precipitation scaled to } \\
\text { NPP. }\end{array}$ \\
\hline $\begin{array}{l}\text { Potter et } \\
\text { al. (1996) }\end{array}$ & & & 9.7 & & $\begin{array}{l}\text { Ecosystem production and soil C-N biosphere model. } S_{\mathrm{NO}_{\mathrm{x}}}= \\
f \text { (gross mineralized N, WFPS). }\end{array}$ \\
\hline $\begin{array}{l}\text { Yienger and } \\
\text { Levy (1995) } \\
\text { (YL95) }\end{array}$ & 1.2 & & 10.2 & 5.5 & $\begin{array}{l}\text { Exponential } T \text { dependence multiplied by discrete wet/dry } \\
\text { biome coefficients; pulsed-N }\end{array}$ \\
\hline $\begin{array}{l}\text { Davidson and } \\
\text { Kingerlee } \\
(1997)\end{array}$ & & & 21 & 13 & $\begin{array}{l}100 \text { measurements ( } 60 \text { refs). Average computed over } 17 \\
\text { landtypes and extrapolated globally. }\end{array}$ \\
\hline $\begin{array}{l}\text { Ganzeveld et } \\
\text { al. (2002) }\end{array}$ & & & 12 & 8 & $\begin{array}{l}\text { Used YL95 to study the sensitivity of a global model to a } \\
\text { multi-layer canopy model vs. a big-leaf canopy approach }\end{array}$ \\
\hline $\begin{array}{l}\text { Jaeglé et } \\
\text { al. (2005) }\end{array}$ & $2.5-4.5$ & & & 8.9 & Satellite inferred emissions from GOME for the year 2000 . \\
\hline $\begin{array}{l}\text { Yan et } \\
\text { al. }(2005)\end{array}$ & $1.08^{6}$ & & 7.4 & 5.0 & $\begin{array}{l}\text { A statistical model was developed based on } 92 \text { measurements } \\
\text { ( } 30 \text { refs) including SOC, pH, landcover, climate, and } \mathrm{N} \text {-input } \\
\text { coupled with exponential } T \text { dependence and pulsed-N. }\end{array}$ \\
\hline $\begin{array}{l}\text { Stehfest and } \\
\text { Bouwman } \\
(2006)\end{array}$ & 1.8 & & & & $\begin{array}{l}\text { A statistical model was developed from } 189(210) \text { NO measure- } \\
\text { ments from } 58 \text { (52) refs. over fertilized (natural) soils. Signifi- } \\
\text { cant variables for fertilized soils: } \mathrm{N} \text { application/content and cli- } \\
\text { mate. Natural soils: biome, } \mathrm{SOC}, \mathrm{pH} \text {, bulk density and drainage. }\end{array}$ \\
\hline $\begin{array}{l}\text { Steinkamp and } \\
\text { Lawrence } \\
(2011)\end{array}$ & & & $10.5 / 33^{7}$ & $8.61 / 26.7^{7}$ & $\begin{array}{l}\text { Updates YL95 wet/dry biome coefficients using } 560 \text { measure- } \\
\text { ments ( } 180 \text { refs). Wet/dry criteria now based on vol. soil mois- } \\
\text { ture. \# biomes increased by } \times 2 \text {, fertilizer maps updated. }\end{array}$ \\
\hline $\begin{array}{l}\text { This study } \\
\text { GEOS-Chem } \\
\text { Original }\end{array}$ & $\begin{array}{l}0.8 \\
(0.62)^{8}\end{array}$ & & 7.4 & 6.2 & YL95 as implemented into GEOS-Chem in Wang et al. (1998) \\
\hline $\begin{array}{l}\text { This study } \\
\text { BDSNP (Year } \\
\text { 2006) }\end{array}$ & $1.8^{8}$ & 0.5 & 10.7 & 9.0 & $\begin{array}{l}\text { Updates YL95 including a continuous dependence on soil mois- } \\
\text { ture and temperature, modified length/strength of pulsed-N } \\
\text { emissions, improved N-fertilizer and manure representation, } \\
\text { and the fertilization } \\
\text { effect of N-deposition to natural soils. }\end{array}$ \\
\hline
\end{tabular}

\footnotetext{
${ }^{1}$ Estimates of $S_{\mathrm{NO}_{\mathrm{x}}}$ resulting from fertilizer and manure-N inputs to soil,

2 above-canopy estimates of $S_{\mathrm{NO}_{\mathrm{x}}}$ resulting from wet and dry-deposited $\mathrm{N}$ inputs to soil,

3 global above-soil estimates of $S_{\mathrm{NO}_{\mathrm{x}}}$,

4 global estimates of $\mathrm{S}_{\mathrm{NO}_{\mathrm{x}}}$ including canopy uptake of $\mathrm{NO}_{2}$,

${ }^{5} \log _{10}(\mathrm{NO}$ flux $)=0.049 \times T_{\mathrm{a}}-0.83, T_{\mathrm{a}}=$ surface air temperature,

$60.57 \mathrm{Tg} \mathrm{N} \mathrm{yr}^{-1}$ from chemical fertilizer application and $0.51 \mathrm{Tg} \mathrm{N} \mathrm{yr}^{-1}$ manure application,

710.5 (33) $\mathrm{Tg} \mathrm{N} \mathrm{yr}^{-1}$ above-soil and $8.61(26.7) \mathrm{Tg} \mathrm{N} \mathrm{yr}^{-1}$ above-canopy if using geometric (arithmetic) mean of $A_{\mathrm{W} / \mathrm{d}}$ calculated over measurements for each landtype,

8 above-soil estimate.
} 


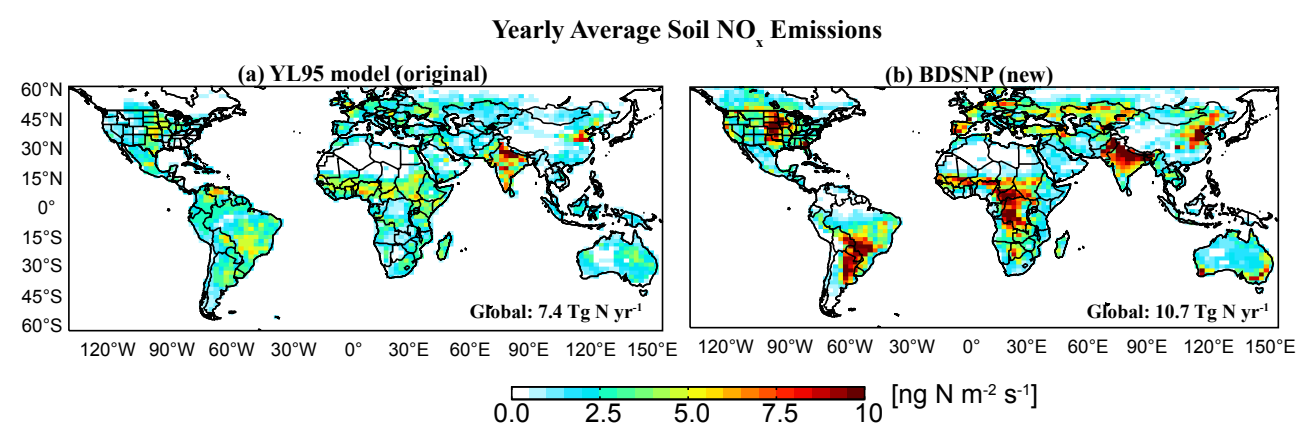

Fig. 1. Comparison of above-soil $\mathrm{NO}_{\mathrm{x}}$ emission inventories. Emissions calculated from (a) the original YL95 parameterization as implemented into GEOS-Chem (Wang et al., 1998) are compared with (b) the updated model (BDSNP) for the year 2006. Calculated global 2006 emissions are listed (lower right). Color bar saturates at $10 \mathrm{ng} \mathrm{N} \mathrm{m}^{-2} \mathrm{~s}^{-1}$.

water cycle than was available at the time YL95 was created, allowing the development of a model that includes additional mechanistic details.

The current implementation of the YL95 scheme in GEOS-Chem, as described in Wang et al. (1998), produces above-soil estimates of $7.4 \mathrm{Tg} \mathrm{N} \mathrm{yr}^{-1}$ for the year 2006 (Fig. 1a). $S_{\mathrm{NO}_{\mathrm{x}}}$ are computed as a function of vegetation type (Olson, 1992), temperature, precipitation history, and fertilizer use:

$S_{\mathrm{NO}_{\mathrm{x}}}$ Flux $=f_{\mathrm{w} / \mathrm{d}}\left(T, A_{\mathrm{w} / \mathrm{d} \text {,biome }}\right) \times P($ precipitation $)+E_{\mathrm{Fert}}$,

where $f_{\mathrm{w} / \mathrm{d}}$ is a constant, linear, or exponential function of soil temperature ( $T$ ) and $A_{\mathrm{w} / \mathrm{d} \text {, biome }}$ is a coefficient to distinguish between vegetation type and soil moisture state. Soils are labeled as either wet (w) or dry (d) with separate temperature dependencies for each, leading to sharp steps in emissions that are independent of soil moisture. This functional relationship is depicted in Fig. 2. $P$ (precipitation) is a scaling factor used to adjust the flux during pulsing events, which is a function of precipitation amount over dry soils. The model treats natural emissions and fertilizer emissions differently. $E_{\text {Fert }}$ represents fertilizer emissions, which in prior versions of GEOS-Chem is set to $2.5 \%$ of total fertilizer applied, evenly emitted over the growing season, and these emissions do not respond to meteorological variables with the same functional form as natural $\mathrm{N}$ emissions. A time series of simulated fertilizer emissions over the central United States $\left(103.75-93.75^{\circ} \mathrm{W}, 27^{\circ}-51^{\circ} \mathrm{N}\right)$ is shown in Fig. 3. In GEOS-Chem a scaling factor is added to account for loss of $\mathrm{NO}_{\mathrm{x}}$ to plant canopy based on Jacob and Bakwin (1991). This canopy reduction factor is not mechanistic in nature; moreover, recent observations provide mixed evidence on the magnitude of such reductions and laboratory measurements of $\mathrm{NO}_{2}$ compensation points in some cases suggest that $\mathrm{NO}_{2}$ should be emitted from forest canopies at low $\mathrm{NO}_{\mathrm{x}}$ concentrations (Raivonen et. al., 2009; Chaparro-Suarez et al., 2011). Ganzeveld et al. (2002) analyzed the sensitivity of a global model to a mechanistic multilayer model of canopy effects relative to a standard (big-leaf) canopy re- duction scheme, and found that although both schemes resulted in similar global emission budgets and similar surface $\mathrm{NO}_{\mathrm{x}}$ flux in regions influenced by anthropogenic emissions, large local differences in surface $\mathrm{NO}_{\mathrm{x}}$ flux occurred in several tropical and sub-tropical regions, hinting at the inadequacy of the big-leaf scheme to model canopy effects at remote sites. Given this uncertainty, we focus on abovesoil estimates from both models (YL95 and BDSNP) here, and stress that future users of the model should implement a canopy reduction scheme they find most appropriate for their application, noting that standard canopy reduction schemes may not accurately represent the temporal or spatial variability in canopy effects. However, to allow comparison with previous studies, we also implement the standard GEOS-Chem canopy reduction scheme and provide values in the text and Table 1 regarding the effects of canopy reduction.

Figure 1a shows yearly averaged $S_{\mathrm{NO}_{\mathrm{x}}}$ from the original implementation of the YL95 scheme in GEOS-Chem. The largest emissions are predicted over Northern Hemisphere agricultural regions (India, northeastern China, and the central United States) and over northern equatorial Africa. Disagreement exists between this estimate and top-down estimates, which indicate that YL95 underestimates emissions by factors of 2-3 in several regions including the United States, Mexico, eastern China, and northern equatorial African grasslands (Jaeglé et al., 2005; Wang et al., 2007; Boersma et al., 2008). Globally, space-based observations of $\mathrm{NO}_{2}$ columns from the Global Ozone Monitoring Experiment (GOME, $40 \times 320 \mathrm{~km}^{2}$ nadir footprint, with global coverage $\sim$ weekly) were used to derive an a posteriori yearly global $S_{\mathrm{NO}_{\mathrm{x}}}$ source of $8.9 \mathrm{Tg} \mathrm{N} \mathrm{yr}^{-1}, 68 \%$ greater than YL95 $S_{\mathrm{NO}_{\mathrm{x}}}$ estimates (Jaeglé et al., 2005). These studies suggest a discrepancy in the functional relationship with soil moisture and temperature and in the representation of $\mathrm{N}$ fertilizer.

There have been several empirical models of $S_{\mathrm{NO}_{\mathrm{x}}}$ introduced since YL95. Similar to YL95, Yan et al. (2005) derived an exponential relationship between $S_{\mathrm{NO}_{\mathrm{x}}}$ and temperature, but added additional coefficients in the exponent to 
account for soil organic carbon, $\mathrm{pH}$, and land cover type. Additionally, they updated the pulsing scheme to include stronger, shorter pulses based on dry-spell length rather than precipitation amount, consistent with more recent studies. Steinkamp and Lawrence (2011) recalculate the wet and dry biome coefficients $\left(A_{\mathrm{w} / \mathrm{d} \text {,biome }}\right)$ used in YL95 with an updated database of 560 measurements. The above studies describe discrete wet and dry states, rather than a continuous dependence on soil moisture. A regional non-linear regression model was created using observations over Europe relating $S_{\mathrm{NO}_{\mathrm{x}}}$ to seven climatic and soil condition variables (Delon et al., 2007). Delon et al. (2008) updated this model for use over Africa and found a continuous dependence on soil moisture was crucial to correctly represent temporal variability in $S_{\mathrm{NO}_{\mathrm{x}}}$.

\section{Soil $\mathrm{NO}_{\mathrm{x}}$ parameterization}

The BDSNP represents $S_{\mathrm{NO}_{\mathrm{x}}}$ in a functional form consistent with measurements and biological and meteorological drivers:

$S_{\mathrm{NO}_{\mathrm{x}}}$ Flux $=A_{\text {biome }}^{\prime}\left(N_{\text {avail }}\right) \times f(T) \times g(\theta) \times P\left(l_{\text {dry }}\right)$.

Fertilizer N, the standing pool of $\mathrm{N}$, and deposited $\mathrm{N}$ are represented in the term $N_{\text {avail }}$. $A_{\text {biome }}^{\prime}$ coefficients are functions of $N_{\text {avail }}$ and the $A_{\text {w,biome }}$ coefficients from YL95, updated based on estimates from Steinkamp and Lawrence (2011). The temperature and soil moisture dependencies $f(T)$ and $g(\theta)$, where $\theta$ is water-filled pore space, are represented as continuous functions. Pulsing $P$ depends on dry spell length, $l_{\text {dry }}$, resulting in stronger, shorter pulses based on the parameterization of Yan et al. (2005). These individual terms are described in detail below. A central tool in the analysis is the GEOS-Chem model which is described in Appendix A.

\subsection{Soil moisture/soil temperature dependence}

The temperature dependence of $S_{\mathrm{NO}_{\mathrm{x}}}$ in the BDSNP combines an exponential dependence on temperature between $0^{\circ} \mathrm{C}$ and $30^{\circ} \mathrm{C}$ (constant at $T>30$ ) and a Poisson function scaling for soil moisture:

$f(T) \times g(\theta)=e^{0.103 T} \times a \theta e^{-b \theta^{2}}$.

The exponential dependence on temperature is identical to that for wet soils in YL95, where 0.103 is the weighted average of temperature dependencies for several biomes. The parameterization for soil moisture effects takes advantage of new meteorological fields available in the GEOS-5 assimilated meteorological product. Water-filled pore space, $\theta$, is defined as the ratio of the volumetric soil moisture content to the porosity (Linn and Doran, 1984). Dividing by porosity acts as a normalizing step that makes $\theta$ satisfy $0 \leq \theta \leq 1$, allowing comparison between soils of different textures (Otter et al., 1999). In the GEOS-Chem meteorological fields, $\theta$ is available for the top $2 \mathrm{~cm}$ of soil, where the majority of $S_{\mathrm{NO}_{\mathrm{x}}}$ originate (Pierce and Aneja, 2000). We note that it is uncertain how well $\theta$ represents real-world water-filled pore space because the parameter has not yet been validated. However, the use of this parameter in the soil parameterization still represents movement towards a more mechanistic approach.

The response of $S_{\mathrm{NO}_{\mathrm{x}}}$ is not monotonic to $\theta . S_{\mathrm{NO}_{\mathrm{x}}}$ are low for the extreme values of $\theta$ (0 and 1). For low values, emissions are water-limited. For high values, denitrification dominates preferentially emitting $\mathrm{N}_{2} \mathrm{O}$ and $\mathrm{N}_{2}$; diffusion of emitted gases through the soil pores is also limited. $S_{\mathrm{NO}_{\mathrm{x}}}$ dependence on soil moisture is thus best described as a Poisson function (Parsons et al., 1996; Otter et al., 1999; Pierce and Aneja, 2000; Kirkman et al., 2001; van Dijk and Meixner, 2001; van Dijk et al., 2002) where the values of $a$ and $b$ are chosen such that the maximum value (unity) occurs for $\theta=0.2$ for arid soils and 0.3 elsewhere. Laboratory and field measurements have found that emissions peak in this range for most soils (Yang and Meixner, 1997; Ormeci et al., 1999).

Figure 2 shows the BDSNP soil moisture/temperature dependence for grasslands compared with YL95. YL95 label soil as either "dry" or "wet" based on the prior two week precipitation and have separate soil temperature dependencies for each. A wet soil is one that has received in excess of $10 \mathrm{~mm}$ of rainfall in the previous two weeks, otherwise, it is dry. For wet soils, emissions are described by a linearly increasing function (with zero intercept) for temperatures between 0 and $10^{\circ} \mathrm{C}$ and an exponentially increasing function for temperatures between $10^{\circ} \mathrm{C}$ and $30^{\circ} \mathrm{C}$. For dry soils, emissions are described by a linearly increasing function for temperatures between 0 and $30^{\circ} \mathrm{C}$. The BDSNP avoids these sharp steps, and is instead a smooth function of soil moisture and temperature, consistent with field and laboratory studies.

\subsection{Pulsing}

Pulsed $S_{\mathrm{NO}_{\mathrm{x}}}$ occur when very dry soil is wetted resulting in a reactivation of water-stressed bacteria. Here, we follow the parameterization by Yan et al. (2005), derived from four field studies which relate pulsed emissions to the length of the antecedent dry period (Johansson and Sanhueza, 1988; Davidson et al., 1992b; Scholes et al., 1997; Martin et al., 1998):

$P\left(l_{\mathrm{dry}}, t\right)=\left[13.01 \ln \left(l_{\mathrm{dry}}\right)-53.6\right] \times e^{-c t}$

$P$ represents the magnitude of the peak flux relative to the pre-wetting flux, and the constant $c$ is a rate constant representing the rise/fall time of the pulse $\left(c=0.068 \mathrm{~h}^{-1}\right)$. The value of $l_{\mathrm{dry}}$ is the antecedent dry period in hours. The two main differences between this treatment and that used by YL95 are that $P_{\text {peak }}$ depends logarithmically on the length of the antecedent dry period and the condition for a pulse is a change in soil moisture rather than rainfall. We use the two-part condition described in Yan et al. (2005) to check for 
(a) YL95

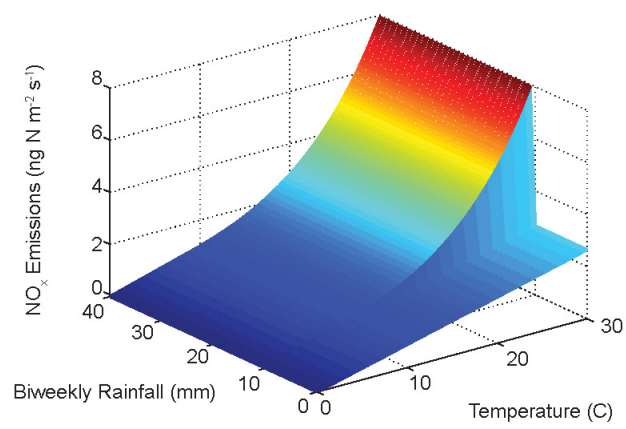

(b) BDSNP

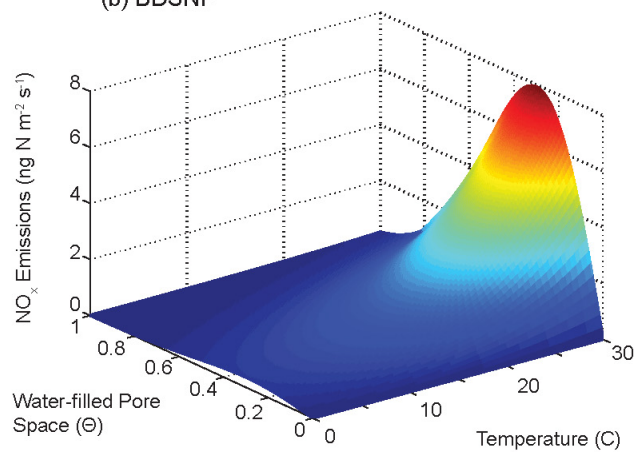

Fig. 2. A three-dimensional representation of the soil $\mathrm{NO}_{\mathrm{x}}$ emissions dependence on soil moisture and temperature from (a) YL95 and (b) BDSNP. The color scheme is a visual aid and follows the vertical axis.

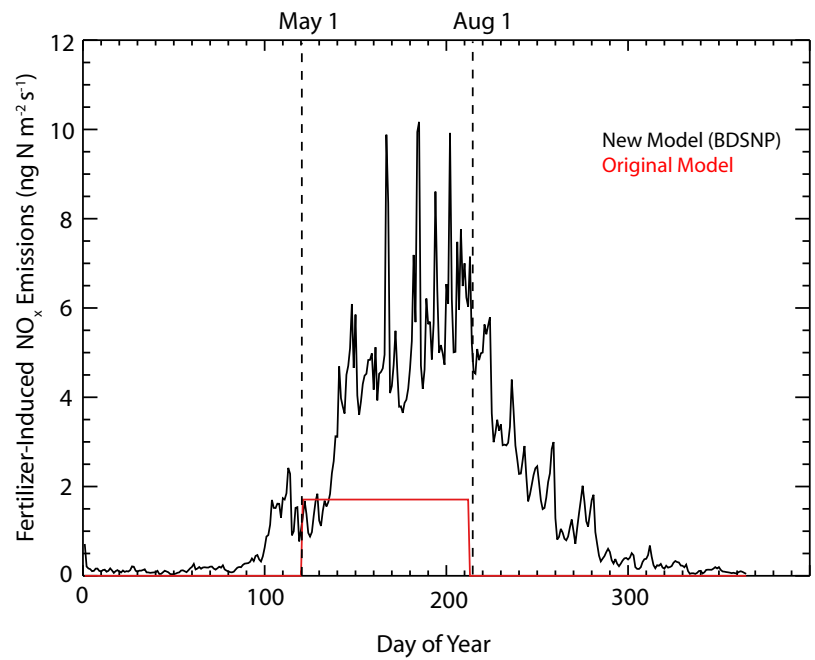

Fig. 3. Mean simulated fertilizer-induced soil $\mathrm{NO}_{\mathrm{x}}$ emissions over the central United States $\left(103.75-93.75^{\circ} \mathrm{W}, 27-51^{\circ} \mathrm{N}\right)$ for the original GEOS-Chem parameterization (red) and the BDSNP (black).

pulsing potential. The dry period is defined as time since volumetric soil moisture content decreased to less than $17.5 \%$ $(v / v)$. A pulse occurs when there is a soil moisture increase of $0.5 \%(v / v)$. Assuming soil bulk density of $1.4 \mathrm{Mg} \mathrm{m}^{-3}$ (typical of seasonally dry savannahs), this is equivalent to $\theta$ $\sim 0.3$ and a $\Delta \theta>0.01$, which we use here.

\subsection{Soil $N$ content}

We use a spatially explicit chemical fertilizer $\left(70 \mathrm{Tg} \mathrm{N} \mathrm{yr}^{-1}\right)$ and manure (128 $\mathrm{Tg} \mathrm{N} \mathrm{yr}^{-1}$ ) dataset from Potter et al. (2010) with a native resolution of $0.5^{\circ} \times 0.5^{\circ}$, valid for the year 2000 (available at http://www.geog.mcgill.ca/ nramankutty/ Datasets/Datasets.html). We assume $37 \%$ of manure N, $47 \mathrm{Tg} \mathrm{N} \mathrm{yr}^{-1}$, remains or is applied as $\mathrm{N}$ input (Sheldrick et al., 2003). To introduce timing, the satellite instruments MODIS and TRMM (Tropical Rainfall Measuring Mission) are used to give information regarding the start and end of the growing season of each model grid square. Zhang et al. (2006) describe an algorithm for deriving growing season start and end dates using a time series of MODIS enhanced vegetation index (EVI). We use growing season dates derived from the MODIS Land Cover Dynamics product (MCD12Q2) averaged over 2001 to 2004 and regridded to the GEOS-Chem model to define the beginning and end of the growing season respectively (Fig. 4) (Ganguly et al., 2010). The standard deviation for this average ranges from 10-40 days for most locations except some tropical forests and deserts where the seasonal variation in EVI is low. However, with the exception of a few tropical areas, fertilizer application rates in these areas are extremely low (Potter et al., 2010) indicating that this variability is not a major source of bias in total emissions. We apply $75 \%$ of the yearly fertilization amount over the first month as a Gaussian distribution around the green-up day and the remaining $25 \%$ is applied evenly over the remaining time in the growing season. This $75 / 25$ treatment is the most typical global farming practice (Matson et al., 1998). We note that no adjustment has been made for regions with two growing seasons or crop rotations in this version; future work will consider how to treat these regions.

To determine the dynamic $\mathrm{N}$ fertilizer available in the soil, we solve the mass-balance equation:

$N_{\text {avail }}(t)=N_{\text {avail }}(0) e^{-t / \tau}+F \times \tau \times\left(1-e^{-t / \tau}\right)$,

where $N_{\text {avail }}$ is the mass of available $\mathrm{N}$ in the soil $\left(\mathrm{ng} \mathrm{N} \mathrm{m}^{-2}\right)$, $F$ is the application rate, and $\tau$ is a decay lifetime. Based on measurements within the top $10 \mathrm{~cm}$ of soil, the decay constant $(\tau)$ for fertilizer $\mathrm{N}$ is chosen as 4 months, with values in the literature for agricultural soils ranging from 2 months to 7 months (Matson et al., 1998; Chen et al., 2004; Russell et al., 2006). The value of $F$ varies over the growing season as described above. At the end of the growing season (Fig. 4), the value of $F$ is zero and the remaining $\mathrm{N}$ fertilizer in the soil is left to decay.

We include wet and dry deposition of $\mathrm{N}$ species as an additional fertilizer source. Online wet and dry deposition rates 


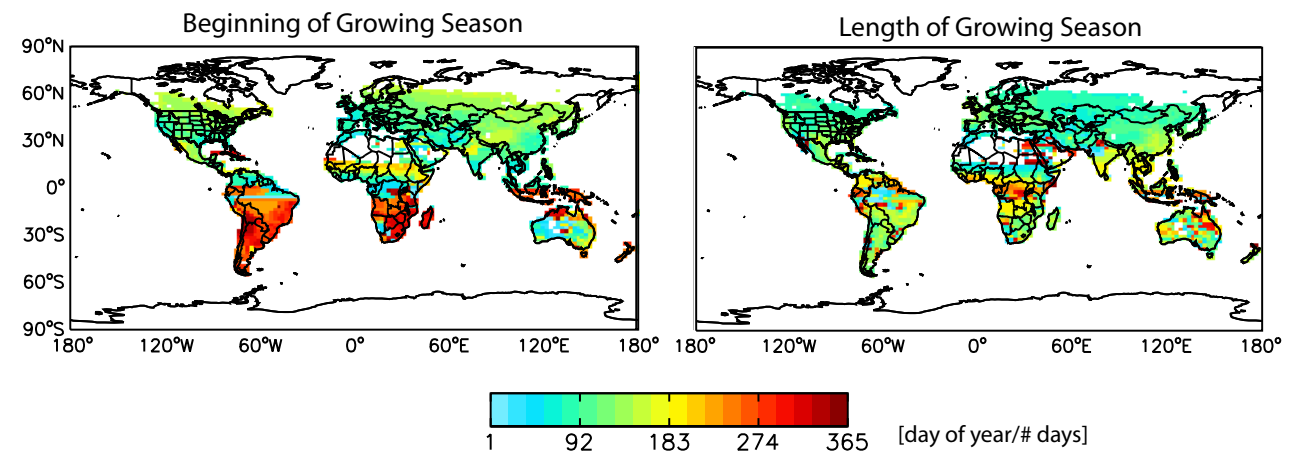

Fig. 4. Beginning of the growing season (day of year) and growing season length (\# days) determined using MODIS enhanced vegetation index as described in the text. Boxes with no chemical fertilizer application are colored white.

of $\mathrm{NH}_{3}, \mathrm{NH}_{4}, \mathrm{HNO}_{3}, \mathrm{NO}_{3}^{-}, \mathrm{NO}_{2}$, and PAN are archived each dynamic time step in GEOS-Chem (Liu et al., 2001). Other $\mathrm{N}$-species add minimal amounts to $\mathrm{N}$-deposition and are neglected. We assume $60 \%$ of this deposited $\mathrm{N}$ enters the soil, with continental values in literature ranging from $55 \%$ to $80 \%$ (Gleick, 1993). The remainder is lost to runoff into waterways. Available $\mathrm{N}$ in the soil is then calculated as with fertilizer (Eq. 5). The decay constant $(\tau)$ for deposition is chosen to be 6 months based on measurements made over lands with natural vegetation, with measurements ranging from 4 months to $1 \mathrm{yr}$ (Hart et al., 1993; Nadelhoffer et al., 1995).

\subsection{Biome emission factors}

The biome emission factor is a crude measure of the $\mathrm{N}$ available in soils and incorporates the available $\mathrm{N}$ from fertilizer and deposition. We choose emission factors $A_{\text {biome }}^{\prime}$ (ng N $\mathrm{m}^{-2} \mathrm{~s}^{-1}$ ) to be functions of the wet biome-dependent emission factors $A_{\mathrm{w}, \text { biome }}$ from Steinkamp and Lawrence (2011), which were derived from 560 measurements for 23 land types, and available nitrogen from fertilizer and deposited $\mathrm{N}$ emissions, $N_{\text {avail }}$ :

$A_{\text {biome }}^{\prime}=A_{\text {w,biome }}+N_{\text {avail }} \times \bar{E}$.

Instead of choosing an emission rate for each box equivalent to $2.5 \%$ of applied $\mathrm{N}$ yearly as done in the YL95 scheme, we scale the emission rate, $\bar{E}$, so that the total global above-soil $\mathrm{NO}_{\mathrm{x}}$ emissions due to fertilizer matches observed estimates of fertilizer emissions of $1.8 \mathrm{Tg} \mathrm{N} \mathrm{yr}^{-1}$ from Stehfest and Bouwman (2006). Figure 3 shows fertilizer-induced $S_{\mathrm{NO}_{\mathrm{x}}}$ averaged over the central Great Plains $\left(27-51^{\circ} \mathrm{N}, 101.25-\right.$ $91.25^{\circ} \mathrm{W}$ ) for 2006 compared with the original scheme implemented into GEOS-Chem. Fertilizer is now treated identically to the natural pool of $\mathrm{N}$ responding to temperature/soil moisture and results in pulsed emissions, rather than a constant flux over the growing season.

\section{Results for the year 2006}

The new model produces above-soil $S_{\mathrm{NO}_{\mathrm{x}}}$ of $10.7 \mathrm{Tg} \mathrm{N} \mathrm{yr}^{-1}$ compared to the original model of $7.4 \mathrm{Tg} \mathrm{N} \mathrm{yr}^{-1}$. Figure 1 shows the annual mean $S_{\mathrm{NO}_{\mathrm{x}}}$ for the original YL95 model as implemented in GEOS-Chem and the new BDSNP presented here for 2006. The largest $S_{\mathrm{NO}_{\mathrm{x}}}$ increases are predicted over fertilized fields in northern midlatitudes, over seasonally dry grasslands of Africa and South America, and over forested regions in central Africa. Decreases are predicted over South American tropical forests and over inundated soils of India and Indonesia during the wet season, all of which were previously held constant and are now allowed to respond to temperature and soil moisture changes. The canopy reduction scheme yields an above-canopy $S_{\mathrm{NO}_{\mathrm{x}}}$ of $9.0 \mathrm{Tg} \mathrm{N}$ $\mathrm{yr}^{-1}$; canopy reduction decreases emissions by $\sim 10-15 \%$ in grasslands and up to $\sim 85 \%$ over forested regions.

The implementation of the soil temperature/soil moisture (Sect. 3.1) treatment decreases $S_{\mathrm{NO}_{\mathrm{x}}}$. The wet coefficients $A_{\text {w,biome }}$ of the original YL95 model are much greater $(\sim \times 7)$ than the dry coefficients $A_{\mathrm{d} \text {,biome, }}$, meaning that emissions remained high throughout the rainy season and low throughout the dry season. The BDSNP represents the onset and eventual inundation of tropical/sub-tropical monsoons, increasing $S_{\mathrm{NO}_{\mathrm{x}}}$ during the dry season relative to the low value forced in the YL95 parameterization, and decreasing emissions over tropical forests now subject to temperature/moisture fluctuations.

The new pulsing scheme increases $S_{\mathrm{NO}_{\mathrm{x}}}$ over seasonally wet grasslands/savannahs. The largest increases are seen over the African Sahel during the onset of the wet season. First rains reactivate bacteria water-stressed from the long dry season, releasing NO as a byproduct (Davidson et al., 1992b). As the excess $\mathrm{N}$ is consumed, $\mathrm{NO}$ emissions remain high compared to the dry season (Serca et al., 1998). Other mechanisms leading to NO pulses with first rainfall include the displacement of NO-enriched air by water, as seen with $\mathrm{CO}_{2}$ and $\mathrm{N}_{2} \mathrm{O}$ (Clough et al., 2000; Huxman et al., 2004), as well as chemodenitrification, the process by which $\mathrm{NO}_{2}^{-}$is 
chemically oxidized to NO (Davidson, 1992a). A similar response is seen over the savannahs/grasslands of South America and Australia. Compared to the original GEOS-Chem implementation of YL95 which used climatological precipitation to determine the "wet" and "dry" criteria of soils and thus exhibited no interannual variability, the new parameterization has a meteorologically driven timing of the onset of the dry and wet season, as well as allowing for drying out of soils. These changes improve the comparison with observations of both magnitude and timing of pulsed $\mathrm{N}$ events. For example, June 2006 was anomalously dry and warm over the US Great Plains, leading to a $50 \%$ increase in emissions with subsequent convective precipitation (Hudman et al., 2010).

The new fertilizer treatment contributes $+1.8 \mathrm{Tg} \mathrm{N} \mathrm{yr}^{-1}$ $S_{\mathrm{NO}_{\mathrm{x}}}$ compared to the original fertilizer implementation which contributed $0.8 \mathrm{Tg} \mathrm{N} \mathrm{yr}^{-1}$. Addition of deposited $\mathrm{N}$ to the pool of available $\mathrm{N}$ contributes an additional $0.5 \mathrm{Tg} \mathrm{Nyr}^{-1}$ to the emissions. These emissions from deposited $\mathrm{N}$ are largest in regions with high anthropogenic $\mathrm{NO}_{\mathrm{x}}$ emissions, notably locations in northeast China and in India, and can contribute significantly ( $>5 \mathrm{ng} \mathrm{N} \mathrm{m}^{-2} \mathrm{~s}^{-1}$ ) to the total $S_{\mathrm{NO}_{\mathrm{x}}}$ in these areas.

\section{Model evaluation}

A detailed validation of regionally and globally applied $S_{\mathrm{NO}_{\mathrm{x}}}$ models with available surface observations is not possible. Field measurements are often set up to test functional relationships in idealized settings, rather than the regionalscale response, and are of varying duration, making scaling highly uncertain and dependent on available measurements. Steinkamp and Lawrence (2011) recalculated the $A_{\mathrm{w} / \mathrm{d} \text {,biome }}$ coefficients used in YL95 with an updated database of 560

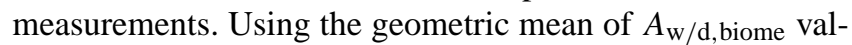
ues calculated over each land type they find a global abovesoil total of $10.5 \mathrm{Tg} \mathrm{Nyr}^{-1}$. Using the arithmetic mean of

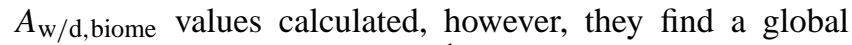
above-soil total of $33 \mathrm{Tg} \mathrm{Nyr}^{-1}$, illustrating the long tail of the measurements, which were shown to fit a log-normal distribution. We use the geometric mean here as it is the more appropriate metric to represent log-normal distributed data, and is most consistent with the upper range expected; global values of above-soil $S_{\mathrm{NO}_{\mathrm{x}}}$ from previous modeling efforts and scaling from field-observations range from 6.6$22 \mathrm{Tg} \mathrm{N} \mathrm{yr}^{-1}$ (Table 1).

To date, revised inventories based on satellite measurements effectively assume a grid cell specific adjustment to source strength which is not understood at the process scale. Satellite observations of $\mathrm{NO}_{2}$ have advanced such that they can now provide daily global coverage at fine spatial resolution. The Ozone Monitoring Instrument (OMI, $13 \times 24 \mathrm{~km}^{2}$ nadir footprint, overpass time $\sim$ 13:45 LT, with global coverage $\sim$ daily), launched aboard the Aura satellite in fall 2004, has high spatio-temporal resolution compared with previous instruments, allowing for stronger constraints on not only the magnitude, but on regional-scale responses governing $S_{\mathrm{NO}_{\mathrm{x}}}$ variability (Hudman et al., 2010). Here, we use tropospheric $\mathrm{NO}_{2}$ vertical column densities from OMI to provide initial constraints on the regional-scale response of $S_{\mathrm{NO}_{\mathrm{x}}}$ to soil moisture, temperature, and fertilization.

\subsection{Sensitivity of $\mathrm{NO}_{2}$ columns to $S_{N} O_{\mathrm{x}}$}

To identify regions where validation is possible, we use GEOS-Chem to determine the locations and time-periods in which $S_{\mathrm{NO}_{\mathrm{x}}}$ are expected to dominate the tropospheric $\mathrm{NO}_{2}$ column. The largest $S_{\mathrm{NO}_{\mathrm{x}}}$ are expected during the Northern Hemisphere late spring (April-June) due to pulsed emissions over seasonally dry soils and summer (June-August) due to chemical fertilizer application and warm temperatures. We include above-soil $S_{\mathrm{NO}_{\mathrm{x}}}$ without canopy reduction and focus our analysis on locations where we expect that canopy effects are relatively small (e.g., grasslands, agriculture), giving us greater confidence in the comparison between the model and observations. We consider above-soil emissions only, because of the uncertainties associated with using the standard canopy reduction scheme versus a more mechanistic scheme (e.g., Ganzeveld et al., 2002); the GEOS-Chem canopy reduction scheme results in a reduction over these regions of $10-15 \%$, consistent with our expectation that effects of canopy reduction are small.

Figure 5a-b shows the GEOS-Chem simulated seasonal mean ratio of soil-derived $\mathrm{NO}_{2}$ column $\left(C_{\mathrm{NO}_{\mathrm{x}}}\right)$ to total column, where $C_{S_{\mathrm{NO}_{\mathrm{x}}}}$ is defined as the difference between a simulation with and without $S_{\mathrm{NO}_{\mathrm{x}}}$. To validate with data from OMI, the model is sampled between 12:00-15:00 LT corresponding to the OMI overpass time. During the onset of the summer monsoon over the northern equatorial tropics, $C_{S_{\mathrm{NO}}}$ is predicted to range from $0-65 \%$ of the total column, with large $S_{\mathrm{NO}_{\mathrm{x}}}$ enhancements over the African Sahel (15$65 \%$, boxed region Fig. 5a). The contribution of $S_{\mathrm{NO}_{\mathrm{x}}}$ over fertilized midlatitudes ranges from $0-60 \%$ (Fig. 5b) and is large during the summer months over the Great Plains of the United States $(0-50 \%$, boxed region Fig. $5 b)$.

$S_{\mathrm{NO}_{\mathrm{x}}}$ are variable day-to-day, reflecting synoptic variability in temperature and pulsing associated with wetting and drying of soils. Figure $5 \mathrm{c}-\mathrm{d}$ shows the ratio of the standard deviation of $C_{S_{\mathrm{NO}}}$ to the standard deviation in the total column without $S_{\mathrm{NO}_{\mathrm{x}}}$. This measure can be used to diagnose the contribution of $S_{\mathrm{NO}_{\mathrm{x}}}$ to observed column variability. Over the African Sahel variability in $C_{S_{\mathrm{NO}}}$ is $5 \times$ greater than the variability in the absence of $S_{\mathrm{NO}_{\mathrm{x}}}$, suggesting daily soil pulsing should be easily distinguishable from other sources of variability. Over most of the industrialized midlatitudes this ratio is $\sim 1$, indicating $S_{\mathrm{NO}_{\mathrm{x}}}$ are not important to the variability in the $\mathrm{NO}_{2}$ column. The Great Plains region is an exception and the variability due to $S_{\mathrm{NO}_{\mathrm{x}}}$ is increased $(\times 2-4)$. Using this metric as a guide, we focus our validation on these two regions. 

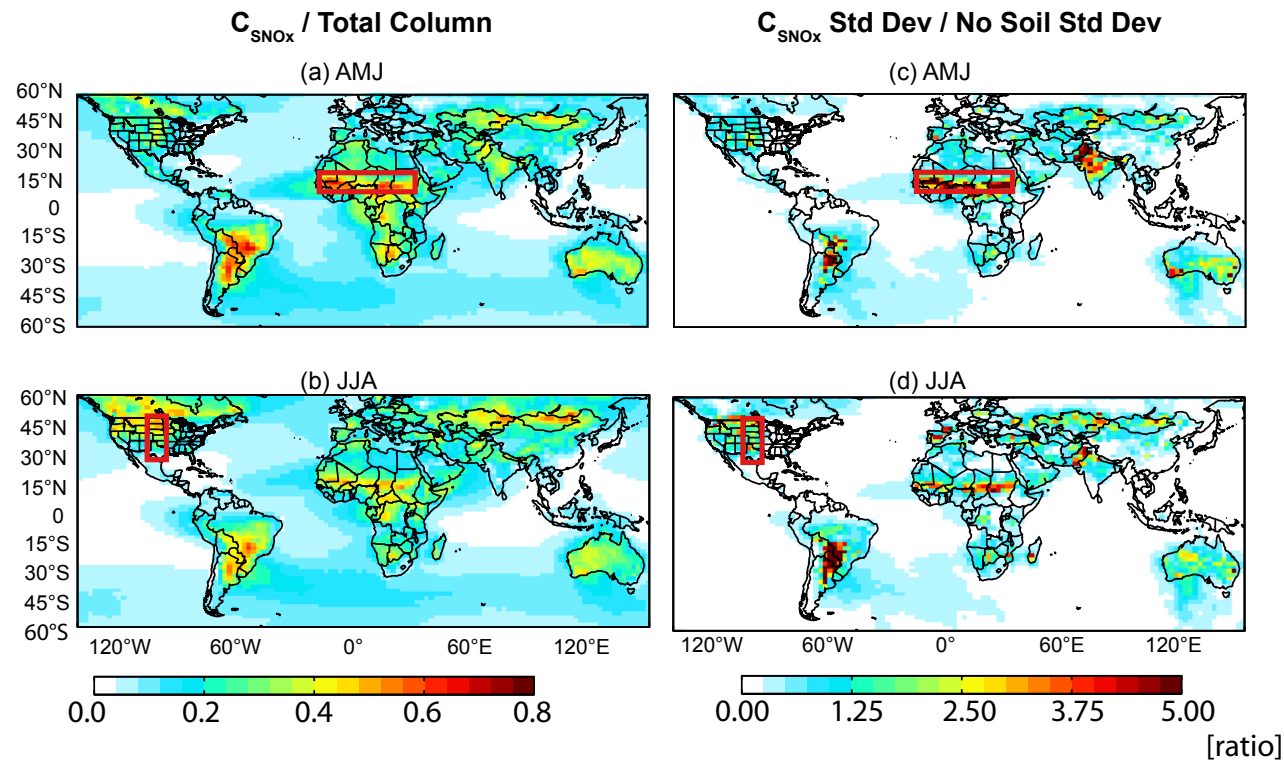

Fig. 5. Sensitivity of simulated tropospheric $\mathrm{NO}_{2}$ column densities to $\mathrm{NO}_{\mathrm{x}}$ emissions from soils for late spring and summer. Shown are (a, b) the mean simulated contribution of soil $\mathrm{NO}_{\mathrm{x}}$ emissions to the tropospheric $\mathrm{NO}_{2}$ column and (c, d) the ratio of the soil-derived $\mathrm{NO}_{2}$ column $\left(C_{S_{\mathrm{NO}_{\mathrm{x}}}}\right)$ standard deviation to the simulated tropospheric $\mathrm{NO}_{2}$ column standard deviation without soil $\mathrm{NO}_{\mathrm{x}}$ emissions. $C_{S_{\mathrm{NO}_{\mathrm{x}}}}$ is defined as the difference in the tropospheric $\mathrm{NO}_{2}$ column between a simulation with and without soil $\mathrm{NO}_{\mathrm{x}}$ emission. Boxed regions show the Sahel region of northern equatorial Africa and the Great Plains agricultural center of the United States.

van der A et al. (2008) use satellite data from the GOME and SCIAMACHY instruments to identify regions where soil $\mathrm{NO}_{\mathrm{x}}$ emissions dominate the observed $\mathrm{NO}_{2}$ column. There are several broad similarities between the regions they identify as major soil $\mathrm{NO}_{\mathrm{x}}$ sources and the locations we identify above (e.g., the Sahel, northern Great Plains), but also some differences (e.g., southern Great Plains). We note that van der A et al. (2008) identify locations as soil-dominant according to the seasonal cycle, as soil emissions peak in the summer while areas not dominated by soil emissions experience wintertime peaks in $\mathrm{NO}_{2}$ column densities. We instead identify locations where soil emissions are a large percentage of the total column and dominate the day-to-day variability in the measured column over a specific time interval (AMJ/JJA). It is possible that soil emissions may contribute a large fraction of $\mathrm{NO}_{2}$ to the total column during summertime in locations identified as e.g., anthropogenic-dominated sources by van der A et al. (2008), and may also dominate daily variability in those locations, accounting for the differences observed. Regardless, the results presented by van der A et al. (2008) increase our confidence that the regions selected for validation here should be highly influenced by soil $\mathrm{NO}_{\mathrm{x}}$ emissions.

\subsection{Validation of fertilizer source: interannual variability over the Great Plains}

Hudman et al. (2010) examined the interannual variability in the $\mathrm{NO}_{2}$ column over North America measured by OMI during 2005-2008. They found that much of the observed variability in June was due to meteorological variability coupled with the large amount of $\mathrm{N}$-fertilizer applied to the region. Dry, warm conditions in June 2006 followed by convective precipitation induced pulsed emissions of $\mathrm{NO}_{\mathrm{x}}$ over the Great Plains with a different timing than in the years 2005, 2007 and 2008. Using OMI tropospheric $\mathrm{NO}_{2}$ column measurements regridded to $0.25^{\circ} \times 0.25^{\circ}$ resolution and a model of $S_{\mathrm{NO}_{\mathrm{x}}}$, they inferred a $50 \%$ increase in $S_{\mathrm{NO}_{\mathrm{x}}}$ and up to a $30 \%$ increase in the tropospheric $\mathrm{NO}_{2}$ column in 2006 relative to the June 2005-2008 mean.

Figure 6 shows the tropospheric $\mathrm{NO}_{2}$ column deviations for June of each year from the June 2005-2008 mean from OMI, and simulated by GEOS-Chem using the BDSNP over the central United States. All column data are regridded daily to $2^{\circ} \times 2.5^{\circ}$ resolution where the cloud radiance fraction is $<50 \%$ and then averaged to produce the monthly mean columns. Several retrievals exist for calculating $\mathrm{NO}_{2}$ column densities from the earthshine radiance observed by OMI. All products begin with the same $\mathrm{NO}_{2}$ slant column densities, determined using a non-linear least squares fit of the ratio of measured radiance to solar irradiance spectrums in the 405$465 \mathrm{~nm}$ window. Differences in the resulting tropospheric $\mathrm{NO}_{2}$ vertical column densities arise from differences in the methodology used to calculate the stratospheric component of the slant column and the tropospheric air mass factor, which converts the tropospheric slant column to vertical column density. Here we compare two retrievals as a measure of uncertainty in the $\mathrm{NO}_{2}$ anomaly (retrievals are described in 

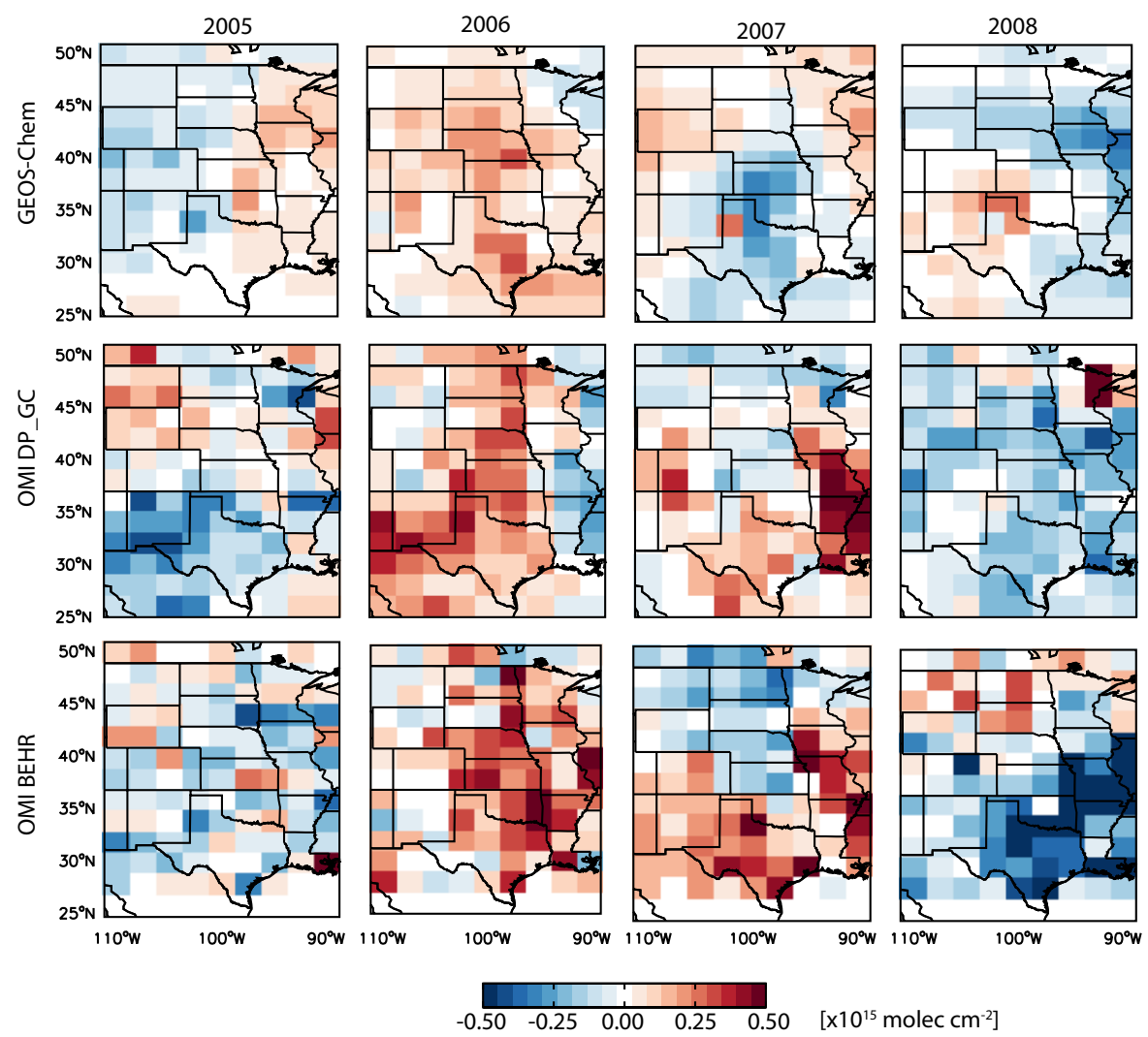

Fig. 6. June mean GEOS-Chem tropospheric $\mathrm{NO}_{2}$ column density anomalies are compared to mean anomalies for $\mathrm{OMI}_{2} \mathrm{NO}_{2}$ from the DP_GC retrieval and the BEHR retrieval. Anomalies are calculated as the difference with the June 2005-2008 mean. Color bar saturates at both ends.

Appendix B): the GEOS-Chem DOMINO Product (DP_GC) (Lamsal et al., 2010), adapted from the DOMINO product (Boersma et al., 2007), and the BErkeley High-Resolution product (BEHR, http://behr.cchem.berkeley.edu) (Russell et al., 2011). The June 2006 mean (total) anomaly over the central Great Plains $\left(27^{\circ}-51^{\circ} \mathrm{N}, 101.25^{\circ}-91.25^{\circ} \mathrm{W}\right.$, boxed region Fig. $5 b, d)$ is $+11 \%(2.5 \mathrm{Gg} \mathrm{N})$ from the DP_GC retrieval and $+11 \%(3.9 \mathrm{Gg} \mathrm{N})$ from the BEHR retrieval. We note that the difference in the total anomaly is related to differences in the stratospheric subtraction and profile shapes used in the retrievals, and also partly due to a discrepancy in the direction of the anomaly in the eastern portion of the region of analysis where the anomaly is less controlled by soil emissions (see Fig. 5). We compare these values to a GEOS-Chem simulation without lightning $\mathrm{NO}_{\mathrm{x}}$ emissions as flash rates in the model are scaled monthly by grid box to match climatology (Murray et al., 2012). This scaling does not reproduce interannual variability in lightning as observed by satellites, leading to June anomalies in modeled $\mathrm{NO}_{2}$ columns that do not match the observed anomalies. This effect was discussed in depth by Hudman et al. (2010), who also used the National Lightning Detection Network to demonstrate that lightning over the Great Plains region was anomalously low in June of 2006, implying that the observed positive anomaly in $\mathrm{NO}_{2}$ columns cannot be due to increased lightning emissions of NO. We acknowledge that lightning emissions are a source of uncertainty in this comparison between satellite observations, which observe any lightningemitted $\mathrm{NO}_{2}$, and the modeled $\mathrm{NO}_{2}$ column anomalies where these emissions are absent. The model is sampled daily between 12:00-15:00 LT to correspond with the OMI overpass time. In GEOS-Chem using the BDSNP the mean anomaly of $+8 \%(2.1 \mathrm{Gg} \mathrm{N})$ is in good agreement with satellite observations, giving us confidence in the soil moisture/temperature relationship used as well as the magnitude of the fertilizer response.

\subsection{Validation of pulsing scheme: monsoonal onset over the African Sahel}

Observations show large pulses of $S_{\mathrm{NO}_{\mathrm{x}}}$ when dry grasslands/savannahs or seasonally dry forests are exposed to rainfall (Johannsson and Sanhueza, 1988; Davidson, 1992b; Harris et al., 1996; Levine et al., 1996; Kirkman et al., 2001; Scholes et al., 1997; Serca et al., 1998; Stewart et al., 2008). To test our parameterization of these pulsing events, we focus on the central Sahel $\left(0-30^{\circ} \mathrm{W}, 12-18^{\circ} \mathrm{N}\right)$, a region of 

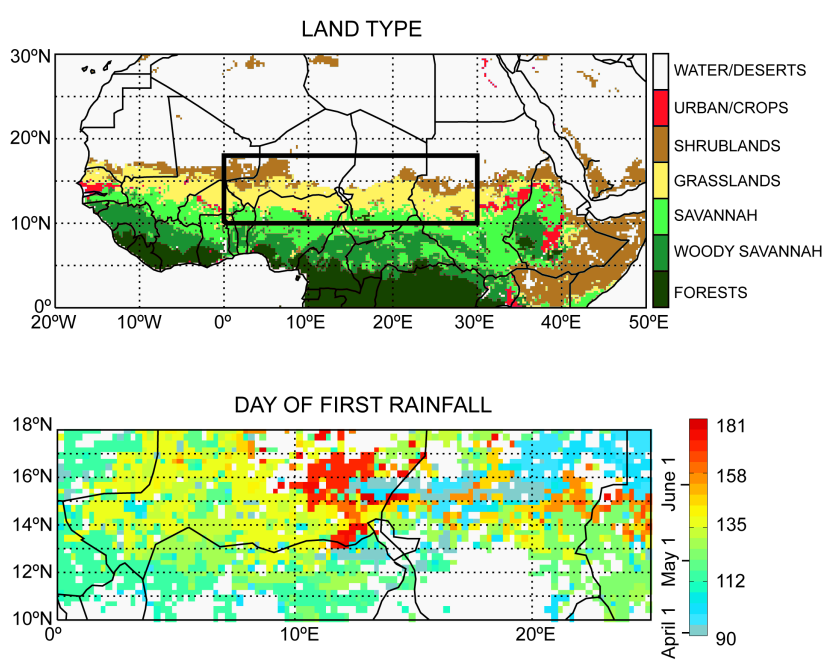

Fig. 7. Land type (top) and first rainfall dates (bottom) over the central Sahel region of northern equatorial Africa $\left(0-30^{\circ} \mathrm{W}\right.$, $10-18^{\circ} \mathrm{N}$, boxed region). Land types were defined using NASA TERRA/MODIS HDF-EOS MOD12Q1 V004 land cover data. First rain is calculated as the date when TRMM total rainfall exceeds $2 \mathrm{~mm}$ in the $24 \mathrm{~h}$ period before the OMI overpass time (13:30 UTC13:30 UTC) following a dry spell (at least 60 days of $<2 \mathrm{~mm}$ day $^{-1}$ ). Regions that do not meet the criteria for dry spell length are shown in white.

transition between the Sudanian savannahs in the south and Sahara desert in the north during spring 2006 (Fig. 7a). The dry season in this region extends from October to June, during which $S_{\mathrm{NO}_{\mathrm{x}}}$ effectively shut off due to lack of moisture, and $\mathrm{N}$ accumulates in the soil (Sect. 2.1). The first rains of the wet season release large pulses of gaseous NO, due to reactivation of water-stressed bacteria, displacement of NO-rich air, and chemodenitrification (Davidson, 1992a, b; Clough et al., 2000; Huxman et al., 2004; Jaeglé et al., 2004). First rains arrive in the southern Sahel in May, with first rains moving further north by early June (Fig. 7b).

In the Yan et al. (2005) parameterization used here, rainfall following a two month dry period results in a $\times 40$ increase in $S_{\mathrm{NO}_{\mathrm{x}}}$, decaying to $\times 8$ in $24 \mathrm{~h}$ and to $\times 1.5$ after $48 \mathrm{~h}$. To test the length of the pulse duration we examine the $\mathrm{OMI} \mathrm{NO}_{2}$ columns from the Standard Product (SP, Level 2, Version 1.0.5, Collection 3) before and following first rains of the 2006 wet season. This analysis was performed with $\mathrm{SP}$, as BEHR is only available over the continental United States and the DP_GC data used was provided at too low a resolution to observe the highly localized pulses; we do not believe that the results would be meaningfully different using any of the other products. The major sources of day to day variation in the $\mathrm{NO}_{2}$ column as measured by OMI at a specific location on earth are the methods for assuming a priori profiles and subtracting the stratosphere, as the slant column is common to all the products. Although there are some systematic differences between the retrievals' definitions of

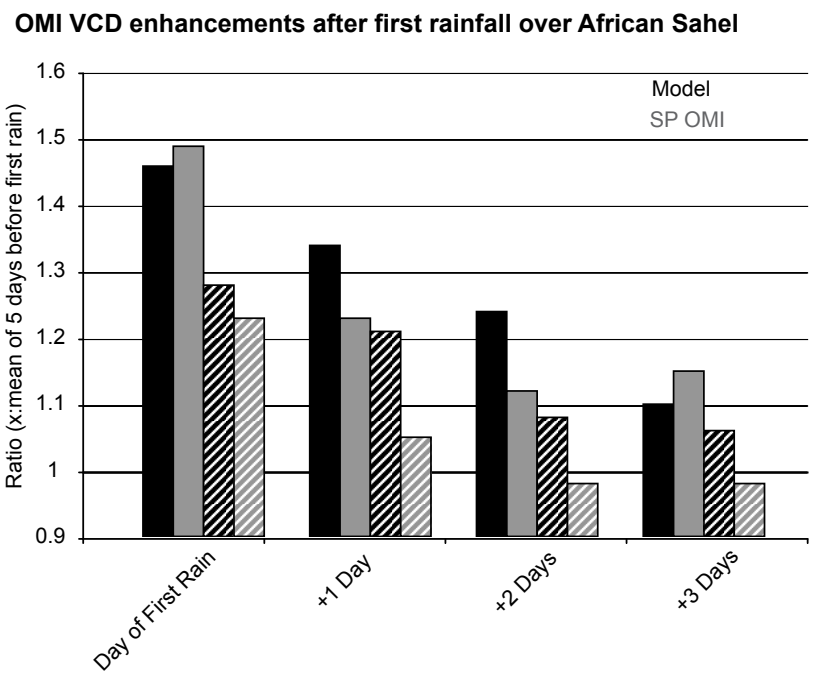

Fig. 8. Mean (solid) and median (diagonal lines) enhancements in the OMI Standard Product (grey) and GEOS-Chem (black) tropospheric $\mathrm{NO}_{2}$ vertical column densities (VCDs) following the first rainfall of the wet season (April-June 2006) over the African Sahel grasslands $\left(0-30^{\circ} \mathrm{W}, 10-18^{\circ} \mathrm{N}\right.$, boxed region in Fig. 7a) are shown. Ratios are taken against the average VCD in the 5 days preceding the first rainfall. All OMI VCD data are averaged daily to $0.25^{\circ} \times 0.25^{\circ}$ latitude/longitude resolution where cloud radiance fraction $<50 \%$.

these qualities, the day-to-day differences are subtle in most cases. An example of the difference in daily variability between SP and DOMINO is shown by Hudman et al. (2010) in Fig. 5; there is little evidence for any systematic difference that would be important for pulsing, except a possible difference in stratospheric subtraction that is important in the vicinity of storm systems. Figure 8 shows mean and median enhancements in $\mathrm{NO}_{2}$ column over central Sahelian grasslands following first rainfall, determined as the first day with precipitation $>2 \mathrm{~mm}$ (as measured by TRMM) following a dry spell (at least 60 days of precipitation $<2 \mathrm{~mm}$ day $^{-1}$ ). All column data are averaged daily to $0.25^{\circ} \times 0.25^{\circ}$ resolution where the cloud radiance fraction is $<50 \%$. The first day of rain is identified and ratios for the day of first rain and subsequent days are taken against the average $\mathrm{NO}_{2}$ column in the 5 days preceding first rainfall in each box; these data are then averaged across all 572 boxes that meet the dry spell criteria. The mean column over the region in the five days preceding first rain is $9.5 \times 10^{14}$ molecules $\mathrm{cm}^{-2}$. Mean (median) columns are $49 \%$ (23\%) higher than in the five days preceding the first rainfall. The following day, columns are still $23 \%(5 \%)$ higher than the background. In subsequent days, the columns are indistinguishable, suggesting pulses last on average 1-2 days, consistent with the representation in the BDSNP. We note that we do not consider the impact of lightning on the observed $\mathrm{NO}_{\mathrm{x}}$ column, but the observed increases occur on the day of first rain only, not subsequent 
rains. Since lightning occurs during both categories of rain events, the observed increases are likely due to pulsing. For comparison to the GEOS-Chem simulation at $2^{\circ} \times 2.5^{\circ}$ resolution, we use a dry spell criteria of $0.025 \mathrm{~mm}$, to account for the coarser resolution. The model predicts the first day of rain $\mathrm{NO}_{2}$ columns to be $46 \%$ (28\%) higher than background. On the following day the column is $34 \%$ (21\%) higher. As in the OMI observations the pulse decays to background by the third day. The large difference between mean and median indicates a non-normal distribution for both observed and modeled values and implies that the pulsing scheme can result in high variability in pulse magnitude depending on dry spell length, $\mathrm{N}_{\mathrm{avail}}$, etc. The columns observed over this region are small with the background columns near the detection limit of the instrument, and the apparent $S_{\mathrm{NO}_{\mathrm{x}}}$ pulses double those values. While the similarity between the measured decay in both observations and model suggest the timing of pulses is appropriately parameterized in the new soil model and the satellite observations are capturing the pulsing, we recommend further research to verify that the magnitude of the pulses observed by OMI is unbiased by the retrieval algorithm.

\section{Conclusions}

We present the BDSNP, a global model of $S_{\mathrm{NO}_{\mathrm{x}}}$ that builds on the YL95 parameterization currently used in most atmospheric chemical transport and air quality models. The BDSNP is designed to better represent the mechanisms that govern the spatial and temporal patterns of $S_{\mathrm{NO}_{\mathrm{x}}}$. The BDSNP includes a continuous dependence on soil moisture and temperature, a representation of biogeochemistry that induces pulsing of the emissions following dry spells, and a detailed spatial and temporal representation of $\mathrm{N}$-inputs both from chem$\mathrm{ical} /$ manure fertilizer and atmospheric $\mathrm{N}$-deposition. The original YL95 scheme as implemented into GEOS-Chem for 2006 yields global above-soil $S_{\mathrm{NO}_{\mathrm{x}}}$ estimates of $7.4 \mathrm{Tg} \mathrm{N}$ $\mathrm{yr}^{-1}$ with $0.8 \mathrm{Tg} \mathrm{N} \mathrm{yr}^{-1}$ from chemical fertilizers compared to this implementation of the BDSNP in GEOS-CHEM of 10.7 $\mathrm{Tg} \mathrm{N} \mathrm{yr}^{-1}$, with $1.8 \mathrm{Tg} \mathrm{N} \mathrm{yr}^{-1}$ from fertilizer/manure $\mathrm{N}$ input $\left(1.5 \%\right.$ of applied $\mathrm{N}$ ) and $0.5 \mathrm{Tg} \mathrm{N} \mathrm{yr}^{-1}$ from atmospheric N-deposition.

In an initial evaluation of the processes in the BDSNP, we use GEOS-Chem to locate time periods and regions where $S_{\mathrm{NO}_{\mathrm{x}}}$ are a large fraction of the tropospheric $\mathrm{NO}_{2}$ column allowing comparison of model predictions to OMI observations that can be interpreted as primarily due to $S_{\mathrm{NO}_{\mathrm{x}}}$. The largest pulsed enhancements in the model are predicted over the African Sahel during the monsoon onset (April-June), comprising $15-65 \%$ of the simulated $\mathrm{NO}_{2}$ column and increasing variability by a factor of 5 . Over this region the OMI mean (median) $\mathrm{NO}_{2}$ on the overpass following first rainfall are $49 \%(23 \%)$ higher than in the five days preceding. The $\mathrm{NO}_{2}$ on the day after rainfall is still $23 \%(5 \%)$ higher. The
BDSNP has similar temporal behaviour in response to rainfall in the Sahel. In the northern midlatitudes, the variability in the $\mathrm{NO}_{2}$ column due to pulsed $S_{\mathrm{NO}_{\mathrm{x}}}$ is smaller than the variability due to synoptic transport of anthropogenic emissions except over the United States Great Plains, where $S_{\mathrm{NO}_{\mathrm{x}}}$ are predicted to contribute as much as $60 \%$ of the column and to increase variability by a factor of 2-4. Over the Great Plains, we find the model is able to reproduce the observed interannual variability over the region giving us confidence in the soil moisture/temperature relationship used as well as the magnitude of the fertilizer response.

$S_{\mathrm{NO}_{\mathrm{x}}}$ represent approximately $15 \%$ of the global N emissions and are a dominant source of atmospheric $\mathrm{N}$ and its variability in many continental regions. The BDSNP attempts to produce a physically realistic response of $S_{\mathrm{NO}_{\mathrm{x}}}$ to meteorological and agricultural drivers, thus providing a new opportunity to study the effects of $S_{\mathrm{NO}_{\mathrm{x}}}$ on the atmospheric chemistry of $\mathrm{O}_{3}$, aerosol, and $\mathrm{OH}$. Further, the potential for linkages to $\mathrm{N}_{2} \mathrm{O}$ emissions through the soil moisture response might one day be explored. Additional studies are needed to assess the accuracy of this parameterization - especially as applied on regional scales and to pulsing associated with individual meteorological events. Such efforts would be able to evaluate the spatiotemporal patterns with more specificity than we have been able to in this initial evaluation of the model.

\section{Appendix A}

\section{GEOS-Chem model}

We simulate the impacts of $S_{\mathrm{NO}_{\mathrm{x}}}$ on tropospheric chemistry using the GEOS-Chem global three-dimensional model of tropospheric chemistry (version 8.03, www.geos-chem.org) driven by assimilated meteorological observations from the NASA Goddard Earth Observing System (GEOS-5). Meteorological fields have a temporal resolution of $6 \mathrm{~h}(3 \mathrm{~h}$ for surface variables and mixing depths) with a native horizontal resolution of $0.5^{\circ} \times 0.667^{\circ}$, degraded to $2^{\circ} \times 2.5^{\circ}$ for input into this simulation using GEOS-Chem. The model is applied to a global simulation of $\mathrm{O}_{3}-\mathrm{NO}_{\mathrm{x}}-\mathrm{VOC}$ chemistry including a fully coupled aerosol mechanism (Bey et al., 2001; Park et al., 2004). The simulations are conducted for 2005-2008 and are initialized on 1 January 2005 with GEOS-Chem fields generated by a 12 -month spin-up simulation at $2^{\circ} \times 2.5^{\circ}$ resolution from chemical climatology.

Global anthropogenic emissions are from EDGAR 3.2FT2000 inventory (Olivier et al., 2001) for the year 2000 (van Donkelaar et al., 2008). These are overwritten regionally with the US Environmental Protection Agency National Emission Inventory for 1999 (EPA-NEI99) NEI 99 with modifications described by Hudman et al. (2007, 2008), including a generalized $50 \%$ decrease in $\mathrm{NO}_{\mathrm{x}}$ emissions from power plants and industry reflecting 1999-2004 reductions 
(Frost et al., 2006). Mexican emissions are from Big Bend Regional Aerosol and Visibility Observational (BRAVO) Study Emissions Inventory for 1999 (Kuhns et al., 2005). Canadian emissions are based on the CAC inventory (http: //www.ec.gc.ca/pdb/cac/) for 2005. East Asian emissions are for the year 2006 with monthly variation based on Zhang et al. (2007). European emissions are from the European Monitoring and Evaluation Programme (EMEP) for 2005. Biomass burning emissions are from the interannual Global Fire Emissions Database version 2 (GFED2) inventory with monthly resolution (van der Werf et al., 2006; Randerson et al., 2007).

$S_{\mathrm{NO}_{\mathrm{x}}}$ are from the BDSNP presented here and the YL95 model as implemented in Wang et al. (1998). Lightning $\mathrm{NO}_{\mathrm{x}}$ flash rates are linked to deep convection following the parameterization of Price and Rind (1992) based on GEOS-5 computed cloud-top heights. Flash rates are scaled based for each grid box on monthly average rates from the Lightning Imaging Sensor and Optical Transient Detector satellite instruments (OTD/LIS) (Sauvage et al., 2007; Murray et al., 2012). $\mathrm{NO}_{\mathrm{x}}$ yield per flash is $125 \mathrm{~mol}$ in the tropics and 500 mol at northern mid-latitudes (north of $30^{\circ} \mathrm{N}$ ) (Hudman et al., 2007) with vertical $\mathrm{NO}_{\mathrm{x}}$ emission profiles from Ott et al. (2010).

For comparison with OMI observations, the model $\mathrm{NO}_{2}$ column is sampled daily between 12:00-15:00 LT corresponding to approximately the OMI overpass time.

\section{Appendix B}

\section{Tropospheric $\mathrm{NO}_{2}$ columns from the Ozone Monitoring Instrument}

The Ozone Monitoring Instrument is a nadir-viewing UV/Visible spectrometer aboard the EOS-AURA satellite launched in July 2004 into a sun-synchronous orbit with a 13:38 local equator crossing time (Boersma et al., 2002). Earthshine radiance and solar irradiance are recorded at $0.5 \mathrm{~nm}$ resolution in the $270-500 \mathrm{~nm}$ window which can be used to derive $\mathrm{NO}_{2}$ slant column densities using the DOAS method (Levelt et al., 2006). The $114^{\circ}$ field of view is distributed over 60 discrete viewing angles on an imaging array detector perpendicular to the flight direction yielding a $2600 \mathrm{~km}$ ground swath, allowing for daily global coverage. Pixel sizes range from $13 \times 24 \mathrm{~km}^{2}$ to $40 \times 128 \mathrm{~km}^{2}$ at the edge of the sampling swath.

We use three independent retrievals of tropospheric $\mathrm{NO}_{2}$ column data from OMI observations described briefly below: the Standard Product (SP) Level 2, Version 1.0.5, Collection 3 available from the NASA Goddard Earth Sciences Data and Information Services Center DISC (http: //daac.gsfc.nasa.gov/Aura/OMI/omno2.shtml) described in Bucsela et al. (2006) and Celarier et al. (2008), the GEOSChem DOMINO Product (DP_GC) described in Lamsal et al. (2010), and the Berkeley High Resolution Retrieval (BEHR) described in Russell et al. (2011). The three products begin with the same $\mathrm{NO}_{2}$ slant column densities. Differences in the resulting tropospheric $\mathrm{NO}_{2}$ vertical column densities arise from the methods used to calculate the stratospheric component of the slant column and the tropospheric air mass factor, which converts the slant column to vertical column density. For all retrievals we exclude pixels with cloud radiance fractions greater than $50 \%$ as determined by the OMI Cloud Data product (OMCLDO2; Acarreta et al., 2004).

\section{B1 Standard product}

The stratospheric contribution to the total column is calculated by masking regions where tropospheric $\mathrm{NO}_{2}$ columns are high $\left(>0.5 \times 10^{15}\right.$ molec. $\left.\mathrm{cm}^{-2}\right)$ and applying a wave2 smoothing in the meridional direction on remaining pixels. The tropospheric AMF is computed using a look-up table based on surface albedo, terrain pressure, viewing parameters and $\mathrm{NO}_{2}$ profile shape. Surface albedo is from a monthly $1^{\circ} \times 1^{\circ}$ database from Koelemeijer et al. (2003). Terrain pressure is from the SDP Toolkit 90 arsec DEM map. $\mathrm{NO}_{2}$ profiles are from a $2^{\circ} \times 2.5^{\circ}$ gridded dataset of annual mean profiles from the GEOS-Chem model. A cross track bias correction is performed as described by Celarier et al. (2008).

\section{B2 DP_GC}

The DP_GC product is based on the DOMINO algorithm retrieval (Level 2, Version 1.0.2, Collection 3) described in detail in Boersma et al. (2007). In the DOMINO algorithm, after cross track bias correction (Boersma et al., 2007), the stratospheric slant column is derived by assimilating OMI $\mathrm{NO}_{2}$ slant columns into the TM4 global chemical transport model run at $3^{\circ} \times 2^{\circ}$ (Dirksen et al., 2011). Surface albedo is from the monthly $1^{\circ} \times 1.25^{\circ}$ combined GOME/TOMS database (Boersma et al., 2004). $\mathrm{NO}_{2}$ vertical profiles and terrain pressure are interpolated from the TM4 model output. The DP_GC replaces these $\mathrm{NO}_{2}$ profiles with GEOS-Chem run at $2^{\circ} \times 2.5^{\circ}$ and includes an additional cross-track bias correction.

\section{B3 BEHR}

The BErkeley High Resolution Retrieval (BEHR) uses the stratospheric subtraction method of the Standard Product above. Tropospheric AMFs are similarly calculated using a look-up table, but with higher spatial and temporal resolution inputs. Surface albedo is from $0.05^{\circ} \times 0.05^{\circ}$ MODIS $\mathrm{MCD} 43 \mathrm{C} 3$, provided as a 16 day average every 8 days. Terrain pressure is from GLOBE $1 \times 1 \mathrm{~km}^{2}$ tropographical database averaged to OMI pixel. $\mathrm{NO}_{2}$ profiles are from a $4 \times 4 \mathrm{~km}^{2}$ monthly WRF-Chem simulation (averaged to OMI pixel). 


\section{B4 Error}

The total error in the tropospheric $\mathrm{NO}_{2}$ column retrieved is $0.67 \times 10^{15}$ molec. $\mathrm{cm}^{-2}$ for the slant column density (Boersma et al., 2007), and $<0.3 \times 10^{15}$ molec. $\mathrm{cm}^{-2}$ for the stratospheric subtraction for all products (Dirksen et al., 2011). Tropospheric AMF errors arise from input parameters of albedo, terrain pressure, and $\mathrm{NO}_{2}$ profile shape, as well as aerosol assumptions and cloud properties. AMF induced $\mathrm{NO}_{2}$ column errors are estimated at $\sim 30 \%$ for clear sky and $\sim 60 \%$ for cloudy conditions (Boersma et al., 2004) for SP.

Acknowledgements. This work was supported by National Aeronautics and Space Administration, grant NNX08AE566. AKM acknowledges support from the Department of Energy Office of Science Graduate Fellowship Program (DOE SCGF), made possible in part by the American Recovery and Reinvestment Act of 2009, administered by ORISE-ORAU under contract no. DE-AC05-06OR23100. LCV acknowledges support from a NASA Earth and Space Science Fellowship Program. We thank Arlene Fiore for helpful suggestions in the early stages of this effort. We thank Navin Ramankutty and Mark Friedl for making the fertilizer MODIS growing season dataset available respectively.

Edited by: L. Ganzeveld

\section{References}

Acarreta, J. R., De Haan, J. F., and Stamnes, P.: Cloud pressure retrieval using the $\mathrm{O} 2-\mathrm{O} 2$ absorption band at $477 \mathrm{~nm}$, J. Geophys. Res., 109, D05204, doi:10.1029/2003JD003915, 2004.

Andreae, M. O. and Crutzen, P. J.: Atmospheric aerosols: Biogeochemical sources and role in atmospheric chemistry, Science, 276, 1052-1058, 1997.

Bertram, T. H., Heckel, A., Richter, A., Burrows, J. P. and Cohen, R. C.: Satellite measurements of daily variations in soil $\mathrm{NO}_{\mathrm{x}}$ emissions, Geophys. Res. Lett., 32, L24812, doi:10.1029/2005GL024640, 2005.

Bey, I., Jacob, D. J., Yantosca, R. M., Logan, J. A., Field, B. D., Fiore, A. M. Li, Q., Liu, H. Y., Mickley, L. J., and Schultz, M. G.: Global modeling of tropospheric chemistry with assimilated meteorology: Model description and evaluation, J. Geophys. Res., 106, 23073-23095, 2001.

Boersma, K. F., Bucsela, E. J., Brinksma, E. J., and Gleason, J. F: $\mathrm{NO}_{2}$, in: OMI Algorithm Theoretical Basis Document, Vol. 4, OMI Trace Gas Algorithms, ATBD-OMI-04 (Version 2), 13-36, 2002.

Boersma, K. F., Eskes, H. J., and Brinksma, E. J.: Error analysis for tropospheric $\mathrm{NO}_{2}$ retrieval from space, J. Geophys. Res., 109, D04311, doi:10.1029/2003JD003962, 2004.

Boersma, K. F., Eskes, H. J., Veefkind, J. P., Brinksma, E. J., van der A, R. J., Sneep, M., van den Oord, G. H. J., Levelt, P. F., Stammes, P., Gleason, J. F., and Bucsela, E. J.: Near-real time retrieval of tropospheric $\mathrm{NO}_{2}$ from OMI, Atmos. Chem. Phys., 7, 2103-2118, doi:10.5194/acp-7-2103-2007, 2007.

Boersma, K. F., Jacob, D. J. , Bucsela, E.J.,. Perring, A. E, Dirksen, R., van der A, R. J., Yantosca, R. M., Park, R. J., Wenig, M. O.,
Bertram, T. H. and Cohen, R. C.: Validation of OMI tropospheric $\mathrm{NO}_{2}$ observations during INTEX-B and application to constrain $\mathrm{NO}_{\mathrm{x}}$ emissions over the eastern United States and Mexico, Atmos. Environ., 42, 4480-4497, 2008.

Bouwman, A. F., L. J. M. Boumans, and Batjes, N. H.: Emissions of $\mathrm{N}_{2} \mathrm{O}$ and $\mathrm{NO}$ from fertilized fields: Summary of available measurement data, Global Biogeochem. Cy., 16, 1058, doi:10.1029/2001GB001811, 2002.

Bucsela, E. J., Celarier, E. A., Wenig, M. O., Gleason, J. F., Veefkind, J. P., Boersma, K. F., and Brinksma, E. J.: Algorithm for $\mathrm{NO}_{2}$ vertical column retrieval from the Ozone Monitoring Instrument, IEEE T. Geosci. Remote Sens., 44, 1245-1258, 2006.

Butterbach-Bahl, K., Kahl, M., Mykhayliv, L., Werner, C., Kiese, R., and Li, C.: A European-wide inventory of soil NO emissions using the biogeochemical models DNDC/Forest-DNDC, Atmos. Environ., 43, 1392-1402, 2009.

Celarier, E. A., Brinksma, E. J., Gleason, J. F., Veefkind, J. P., Cede, A., Herman, J. R., Ionov, D., Goutail, F., Pommereau, J. -P., Lambert, J. -C., van Roozendael, M., Pinardi, G., Wittrock, F., Schönhardt, A., Richter, A., Ibrahim, O. W., Wagner, T., Bojkov, B., Mount, G., Spinei, E., Chen, C. M., Pongetti, T. J., Sander, S. P., Bucsela, E. J., Wenig, M. O., Swart, D. P. J., Volten, H., Kroon, M., and Levelt, P. F.: Validation of Ozone Monitoring Instrument nitrogen dioxide columns, J. Geophys. Res., 113, D15S15, doi:10.1029/2007JD008908, 2008.

Chaparro-Suarez, I. G., Meixner, F. X., and Kesselmeier, J.: Nitrogen dioxide $\left(\mathrm{NO}_{2}\right)$ uptake by vegetation controlled by atmospheric concentrations and plant stomatal aperture, Atmos. Environ., 45, 5742-5750, 2011.

Chen, X., F. Zhang, V. Römheld, D. Horlacher, R. Schulz, M. Böning-Zilkens, P. Wang, and Claupein, W.: $\mathrm{N}_{2} \mathrm{O}$ and NO production in various Chinese agricultural soils by nitrification, Soil Biol. Biochem., 36, 953-963, 2004.

Clough, T. J., Sherlock, R. R., and Cameron, K. C.: Entrapment and displacement of nitrous oxide in a drained pasture soil, Nutr. Cycl. in Agroecosyst., 57, 191-193, 2000.

Davidson, E. A.: Sources of nitric oxide and nitrous oxide following wetting of dry soil, Soil Sci. Soc. Am. J., 56, 95-102, 1992a.

Davidson, E. A.: Pulses of nitric oxide and nitrous oxide flux following the wetting of dry soil: An assessment of probable sources and importance relative to annual fluxes, Ecol. Bull., 42 , 149155, 1992 b.

Davidson, E. A. and Kingerlee, W.: A global inventory of nitric oxide emissions from soils, Nutr. Cycl. Agroecosyst., 48, 37-50, 1997.

Delon C., Serca, D., Boissard, C., Dupont, R., Dutot, A., Laville, P., de Rosnay, P., and Delmas, R.: Soil NO emissions modeling using artificial neural network, Tellus B, 59B, 502-513, 2007.

Delon, C., Reeves, C. E., Stewart, D. J., Serça, D., Dupont, R., Mari, C., Chaboureau, J.-P., and Tulet, P.: Biogenic nitrogen oxide emissions from soils - impact on $\mathrm{NO}_{\mathrm{x}}$ and ozone over West Africa during AMMA (African Monsoon Multidisciplinary Experiment): modelling study, Atmos. Chem. Phys., 8, 2351-2363, doi:10.5194/acp-8-2351-2008, 2008.

Dentener, F. J. and Crutzen, P. J.: Reaction of $\mathrm{N}_{2} \mathrm{O}_{5}$ on tropospheric aerosols - impact on the global distributions of $\mathrm{NO}_{\mathrm{x}}, \mathrm{O}_{3}$, and OH, J. Geophys. Res.-Atmos., 98, 7149-7163, 1993.

Dirksen, R. J., Boersma, K. F., Eskes, H. J., Ionov, D. V., Bucsela, E. J., Levelt, P. F., and Kelder, H. M.: Evaluation of strato- 
spheric $\mathrm{NO}_{2}$ retrieved from the Ozone Monitoring Instrument: Intercomparison, diurnal cycle, and trending, J. Geophys. Res., 116, D08305, doi:10.1029/2010JD014943, 2011.

Emmons, L. K., Walters, S., Hess, P. G., Lamarque, J.-F., Pfister, G. G., Fillmore, D., Granier, C., Guenther, A., Kinnison, D., Laepple, T., Orlando, J., Tie, X., Tyndall, G., Wiedinmyer, C., Baughcum, S. L., and Kloster, S.: Description and evaluation of the Model for Ozone and Related chemical Tracers, version 4 (MOZART-4), Geosci. Model Dev., 3, 43-67, doi:10.5194/gmd3-43-2010, 2010.

Firestone, M. K. and Davidson, E. A.: Microbiological basis of NO and $\mathrm{N}_{2} \mathrm{O}$ production and consumption in soil, in: Exchange of trace gases between terrestrial ecosystems and the atmosphere, edited by: Andreae, M. O. and Schimel, D. S., Wiley, Chichester, 7-21, 1989.

Frost, G. J., McKeen, S. A., Trainer, M., Ryerson, T. B., Neuman, J. A., Roberts, J. M., Swanson, A., Holloway, J. S., Sueper, D. T., Fortin, T., Parrish, D. D., Fehsenfeld, F. C., Flocke, F., Peckham, S. E., Grell, G. A., Kowal, D., Cartwright, J., Auerbach, N., and Habermann, T.: Effects of changing power plant $\mathrm{NO}_{\mathrm{x}}$ emissions on ozone in the eastern United States: Proof of concept, J. Geophys. Res., 111, D12306, doi:10.1029/2005JD006354, 2006.

Galbally, I. E. and Roy, C. R.: Loss of fixed nitrogen from soils by nitric oxide exhalation, Nature, 275, 734-735, 1978.

Galloway, J. N., Dentener, F. J., Capone, D. G., Boyer, E. W., Howarth, R. W., Seitzinger, S. P., Asner, G. P., Cleveland, C. C., Green, P. A., Holland, E. A., Karl, D. M., Michaels, A. F., Porter, J. H., Townsend, A. R., and Vorosmarty, C. J.: Nitrogen cycles: past, present, and future, Biogeochemistry, 70, 153-226, 2004.

Ganguly, S., Friedl, M. A., Tan, B., Zhang, X., and Verma, M.: Land surface phenology from MODIS: Characterization of the Collection 5 global land cover dynamics product, Remote Sens. Environ., 114, 1805-1816, 2010.

Ganzeveld, L. N., Lelieveld, J., Dentener, F. J., Krol, M. C., Bouwman, A. J., and Roelofs, G.-J.: Global soil-biogenic $\mathrm{NO}_{\mathrm{x}}$ emissions and the role of canopy processes, J. Geophys. Res., 107, 4298, doi:10.1029/2001JD001289, 2002.

Gleick, P. H.: Water in Crisis, Oxford University Press, New York, 1993.

Harris, G. W., Wienhold, F. G., and Zenker, T.: Airborne observations of strong biogenic $\mathrm{NO}_{\mathrm{x}}$ emissions from the Namibian Savanna at the end of the dry season, J. Geophys. Res.-Atmos., 101, 23707-23711, 1996.

Hart, S. C., Firestone, M. K., Paul, E. A., and Smith, J. L.: Flow and fate of soil nitrogen in an annual grassland and a young mixedconifer forest, Soil Biol. Biochem., 25, 431-442, 1993.

Holland, E. A., Dentener, F. J., and Braswell, B. H.: Contemporary and pre-industrial global reactive nitrogen budgets, Biogeochemistry, 46, 7-43, doi:10.1023/A:1006148011944, 1999.

Hudman, R. C., Jacob, D. J., Turquety, S., Leibensperger, E. M., Murray, L. T., Wu, S., Gilliland, A. B., Avery, M., Bertram, T. H., Brune, W., Cohen, R. C., Dibb, J. E., Flocke, F. M., Fried, A., Holloway, J., Neuman, J. A., Orville, R., Perring, A., Ren, X., Sachse, G. W., Singh, H. B., Swanson, A., and Wooldridge, P. J.: Surface and lightning sources of nitrogen oxides over the United States: Magnitudes, chemical evolution, and outflow, J. Geophys. Res., 112, D12S05, doi:10.1029/2006JD007912, 2007.

Hudman, R. C., Murray, L. T., Jacob, D. J., Millet, D. B., Turquety, S., Wu, S., Blake, D. R., Goldstein, A. H., Holloway,
J., and Sachse, G. W.: Biogenic vs. anthropogenic sources of CO over the United States, Geophys. Res. Lett., 35, L04801, doi:10.1029/2007GL032393, 2008.

Hudman, R. C., Russell, A. R., Valin, L. C., and Cohen, R. C.: Interannual variability in soil nitric oxide emissions over the United States as viewed from space, Atmos. Chem. Phys., 10, 99439952, doi:10.5194/acp-10-9943-2010, 2010.

Huxman, T. E., Snyder, K. A., Tissue, D., Leffler, A. J., Ogle, K., Pockman, W. T., Sandquist, D. R., Potts, D. L., and Schwinning, S.: Precipitation pulses and carbon fluxes in semiarid and arid ecosystems, Oecologia, 141, 254-268, 2004.

Jacob, D. J. and Bakwin, P. S.: Cycling of $\mathrm{NO}_{\mathrm{x}}$ in tropical forest canopies and its implications for the global source of biogenic $\mathrm{NO}_{\mathrm{x}}$ to the atmosphere, American Society of Microbiology, Washington DC, 1991.

Jaeglé, L., Steinberger, L., Martin, R. V., and Chance, K.: Global partitioning of $\mathrm{NO}_{\mathrm{x}}$ sources using satellite observations: Relative roles of fossil fuel combustion, biomass burning and soil emissions, Faraday Discuss., 130, 407-423, 2005.

Johansson, C. and Sanhueza, E.: Emission of NO from savanna soils during the rainy season, J. Geophys. Res., 93, 14193-14198, 1988.

Kirkman, G. A., Yang, W. X., and Meixner, F. X.: Biogenic nitric oxide emissions upscaling: An approach for Zimbabwe, Global Biogeochem. Cy., 15, 1005-1020, 2001.

Koelemeijer, R. B. A., de Haan, J. F., and Stammes, P.: A database of spectral surface reflectivity in the range $335-772 \mathrm{~nm}$ derived from 5.5 years of GOME observations, J. Geophys. Res., 108, 4070, doi:10.1029/2002JD002429, 2003.

Kuhns, H., Knipping, E. M., and Vukovich, J. M.: Development of a United States-Mexico emissions inventory for the Big Bend Regional Aerosol and Visibility Observational (BRAVO) Study, JAPCA J. Air Waste M., 55, 677-692, 2005.

Lamsal, L. N., Martin, R. V., van Donkelaar, A., Celarier, E. A., Bucsela, E. J., Boersma, K. F., Dirksen, R., Luo, C., and Wang, Y.: Indirect validation of tropospheric nitrogen dioxide retrieved from the OMI satellite instrument: Insight into the seasonal variation of nitrogen oxides at northern midlatitudes, J. Geophys. Res., 115, D05302, doi:10.1029/2009JD013351, 2010.

Levelt, P. F., Gijsbertus, H. J., van den Oord, H. J., Dobber, M. R., Mälkki, A., Visser, H., de Vries, J., Stammes, P., Lundell, J. O. V., and Saari, H.: The Ozone Monitoring Instrument, IEEE T. Geosci. Remote Sens., 44, 1093-1101, 2006.

Levine, J. S., Winstead, E. L., Parsons, D. A. B., Scholes, M. C., Scholes, R. J., Cofer, W. R. III, Cahoon, D. R. Jr., and Sebacher, D. I.: Biogenic soil emissions of nitric oxide (NO)and nitrous oxide $\left(\mathrm{N}_{2} \mathrm{O}\right)$ from savannas in South Africa: The impact of wetting and burning, J. Geophys. Res., 101, 23689-23697, 1996.

Lin, J.-T.: Satellite constraint for emissions of nitrogen oxides from anthropogenic, lightning and soil sources over East China on a high-resolution grid, Atmos. Chem. Phys., 12, 2881-2898, doi:10.5194/acp-12-2881-2012, 2012.

Linn, D. M. and Doran, J. W.: Effect of water-filled pore space on carbon dioxide and nitrous oxide production in tilled and nontilled soils, Soil Sci. Soc. Am. J., 48, 1267-1272, 1984.

Liu, H., Jacob, D. J., Bey, I., and Yantosca, R. M.: Constraints from $210 \mathrm{~Pb}$ and $7 \mathrm{Be}$ on wet deposition and transport in a global threedimensional chemical tracer model driven by assimilated meteorological fields, J. Geophys. Res., 106, 12109-12128, 2001. 
Martin, R. E., Scholes, M. C., Mosier, A. R., Ojima, D. S., Holland, E. A., and Parton, W. J.: Controls on annual emissions of nitric oxide from soils of the Colorado shortgrass steppe, Global Biogeochem. Cycles, 12, 81-91, 1998.

Martin, R. V., Jacob, D. J., Yantosca, R. M., Chin, M., and Ginoux, P.: Global and regional decreases in tropospheric oxidants from photochemical effects of aerosols, J. Geophys. Res.-Atmos., 108, 4097, doi:10.1029/2002JD002622, 2003.

Matson, P. A., Naylor, R. L., and Ortiz-Monasterio, I., Integration of environmental, agronomic, and economic aspects of fertilizer management, Science, 280, 112-115, 1998.

Meixner, F. X. and Yang, W. X.: Biogenic emissions of nitric oxide and nitrous oxide from arid and semi-arid land, 233-255, in: Dryland Ecohydrology, edited by: D'Odorico, P. and Porporato, A., 233-255, Dordrecht, Berlin Heidelberg New York (ISBN: 14020-4261-2), 2006.

Muller, J.-F.: Geographical Distribution and Seasonal Variation of Surface Emissions and Deposition Velocities of Atmospheric Trace Gases, J. Geophys. Res., 97, D43787, doi:10.1029/91JD02757, 1992.

Murray, L. T., Jacob, D. J., Logan, J. A., Hudman, R. C., and Koshak, W. J.: Optimized regional and interannual variability of lightning in a global chemical transport model constrained by LIS/OTD satellite data, J. Geophys. Res., in press, 2012.

Nadelhoffer, K. J., Downs, M., Fry, B. Aber, J. D., Magill, A. H., and Melillo, J. M.: The fate of $15 \mathrm{~N}$-labeled nitrate additions to a northern hardwood forest in eastern Maine, USA, Oecologia, 103, 292-301, 1995.

Olivier, J. G. J., Berdowski, J. J. M., Peters, J. A. H. W., Bakker, J., Visschedijk, A. J. H., and Bloos, J. P. J.: Applications of EDGAR, including a description of EDGAR 3.2: Reference database with trend data for 1970-1995, Tech. Rep., RIVM Bilthovan, RIVM report, 773301001/NRP report 4, 2001.

Olson, J.: World Ecosystems (WEI.4): Digital raster data on a 10 minute geographic $1080 \times 2160$ grid, in Global ecosystems database, version 1.0: Disc A, edited by: NOAA Natl. Geophys. Data Center, Boulder, Colorado, 1992.

Ormeci, B., Sanin, S. L., and Pierce, J. J.: Laboratory study of NO flux from agricultural soil: Effects of soil moisture, $\mathrm{pH}$, and temperature, J. Geophys. Res., 104, 1621-1629, 1999.

Ott, L. E., Pickering, K. E., Stenchikov, G. L, Allen, D. J., DeCaria, A. J., Ridley, B., Lin, R.-F., Lang, S., and Tao, W.-K.: Production of lightning $\mathrm{NO}_{\mathrm{x}}$ and its vertical distribution calculated from three-dimensional cloud-scale chemical transport model simulations, J. Geophys. Res., 115, D04301, doi:10.1029/2009JD011880, 2010.

Otter, L. B., Yang, W. X., Scholes, M. C., and Meixner, F. X.: Nitric oxide emissions from a southern African savanna, J. Geophys. Res., 105, 20697-20706, 1999.

Park, R. J., Jacob, D. J., Field, B. D., Yantosca, R. M., and Chin, M.: Natural and transboundary pollution influences on sulfate-nitrate-ammonium aerosols in the United States: Implications for policy, J. Geophys. Res., 109, D15204, doi:10.1029/2003JD004473, 2004.

Parsons, D. A., Scholes, M. C., Scholes, R. J., and Levine, J. S.: Biogenic NO emissions from savanna soils as a function of fire regime, soil type, soil nitrogen, and water status, J. Geophys. Res., 101, 23683-23688, 1996.
Parton, W. J., Holland, E. A., Del Grosso, S. J., Hartman, M. D., Martin, R. E., Mosier, A. R., Ojima, D. S., and Schimel, D. S.: Generalized model for $\mathrm{NO}_{\mathrm{x}}$ and $\mathrm{N}_{2} \mathrm{O}$ emissions from soils, J. Geophys. Res.-Atmos., 106, 17403-17419, 2001.

Phoenix, G. K., Hicks, W. K., Cinderby, S., Kuylenstierna, J. C. I., Stock, W. D., Dentener, F. J., Giller, K. E., Austin, A. T., Lefroy, R. D. B., Gimeno, B. S., Ashmore, M. R., and Ineson, P.: Atmospheric nitrogen deposition in world biodiversity hotspots: the need for a greater global perspective in assessing $\mathrm{N}$ deposition impacts, Glob. Change Biol., 12, 470-476, 2006.

Pierce, J. J. and Aneja, V. P.: Nitric oxide emissions from engineered soil systems, J. Environ. Eng., 126, 225-232, 2000.

Price, C. and Rind, D.: A simple lightning parameterization for calculating global lightning distributions, J. Geophys. Res., 97, 9919-9933, doi:10.1029/92JD00719, 1992.

Potter, C. S., Matson, P. A., Vitousek, P. M., and Davidson, E. A.: Process modeling of controls on nitrogen trace gas emissions from soils worldwide, J. Geophys. Res., 101, 1361-1377, 1996.

Potter, P., Ramankutty, N., Bennett, E. M., and Donner, S. D.: Characterizing the spatial patterns of global fertilizer application and manure production, Earth Interact., 14, 1-22, 2010.

Raivonen, M., Vesala, T., Pirjola, L., Altimir, N., Keronen, P., Kulmala, M., and Hari, P.: Compensation point of $\mathrm{NO}_{\mathrm{x}}$ exchange: Net result of $\mathrm{NO}_{\mathrm{x}}$ consumption and production, Agr. Forest Meteorol., 149, 1073-1081, 2009.

Randerson, J. T., van der Werf, G. R., Giglio, L., Collatz, G. J., and Kasibhatla, P. S.: Global Fire Emissions Database, Version 2 (GFEDv2.1), Data set, from Oak Ridge National Laboratory Distributed Active Archive Center, Oak Ridge, Tennessee, USA, doi:10.3334/ORNLDAAC/849, available at: http: //daac.ornl.gov/, 2007.

Russell, A. R., Perring, A. E., Valin, L. C., Bucsela, E. J., Browne, E. C., Wooldridge, P. J., and Cohen, R. C.: A high spatial resolution retrieval of $\mathrm{NO}_{2}$ column densities from OMI: method and evaluation, Atmos. Chem. Phys., 11, 8543-8554, doi:10.5194/acp-11-8543-2011, 2011.

Russell, C. A., Dunn, B. W., Batten, G. D., Williams, R. L., and Angus, J. F.: Soil tests to predict optimum fertilizer nitrogen rate for rice, Field Crops Research, 97, 286-301, 2006.

Sauvage, B., Martin, R. V., van Donkelaar, A., Liu, X., Chance, K., Jaeglé, L., Palmer, P. I., Wu, S., and Fu, T.-M.: Remote sensed and in situ constraints on processes affecting tropical tropospheric ozone, Atmos. Chem. Phys., 7, 815-838, doi:10.5194/acp-7-815-2007, 2007.

Scholes, M. C., Martin, R., Scholes, R. J., Parsons, D., and Winstead, E.: NO and $\mathrm{N}_{2} \mathrm{O}$ emissions from savanna soils following the first simulated rains of the season, Nutr. Cycling Agroecosyst., 48, 115-122, 1997.

Serça, D., Delmas, R., Le Roux, X., Parsons, D. A. B., Scholes, M. C., Abbadie, L., Lensi, R., Ronce, O., and Labrouc, L.: Comparison of nitrogen monoxide emissions from several African tropical ecosystems and influence of season and fire, Global Biogeochem. Cy., 12, 637-651, 1998.

Sheldrick, W., Syers, J. K., and Lingard, J.: Contribution of livestock excreta to nutrient balances, Nutr. Cycl. Agroecosyst., 66, 119-131, 2003.

Stehfest, E. and Bouwman, L.: $\mathrm{N}_{2} \mathrm{O}$ and $\mathrm{NO}$ emission from agricultural fields and soils under natural vegetation: summarizing available measurement data and modeling of global annual emissions, 
Nutr. Cycl. Agroecosyst., 74, 207-228, doi:10.1007/s10705-0069000-7, 2006.

Steinkamp, J. and Lawrence, M. G.: Improvement and evaluation of simulated global biogenic soil NO emissions in an AC-GCM, Atmos. Chem. Phys., 11, 6063-6082, doi:10.5194/acp-11-60632011, 2011.

Steinkamp, J., Ganzeveld, L. N., Wilcke, W., and Lawrence, M. G.: Influence of modelled soil biogenic NO emissions on related trace gases and the atmospheric oxidizing efficiency, Atmos. Chem. Phys., 9, 2663-2677, doi:10.5194/acp-9-2663-2009, 2009.

Stewart, D. J., Taylor, C. M., Reeves, C. E., and McQuaid, J. B.: Biogenic nitrogen oxide emissions from soils: impact on $\mathrm{NO}_{\mathrm{x}}$ and ozone over west Africa during AMMA (African Monsoon Multidisciplinary Analysis): observational study, Atmos. Chem. Phys., 8, 2285-2297, doi:10.5194/acp-8-2285-2008, 2008.

van der A, R. J., Eskes, H. J., Boersma, K. F., van Noije, T. P. C., Van Roozendael, M., De Smedt, I., Peters, D. H. M. U., and Meijer, E. W.: Trends, seasonal variability and dominant $\mathrm{NO}_{\mathrm{x}}$ source derived from a ten year record of $\mathrm{NO}_{2}$ measured from space, J. Geophys. Res.-Atmos., 113, D04302, doi:10.1029/2007JD009021, 2008.

van der Werf, G. R., Randerson, J. T., Giglio, L., Collatz, G. J., Kasibhatla, P. S., and Arellano Jr., A. F.: Interannual variability in global biomass burning emissions from 1997 to 2004, Atmos. Chem. Phys., 6, 3423-3441, doi:10.5194/acp-6-3423-2006, 2006.

van Dijk, S. M. and Meixner, F. X.: Production and consumption of $\mathrm{NO}$ in forest and pasture soils from the Amazon basin, Water Air Soil Pollut., 1, 119-130, 2001.

van Dijk, S. M., Gut, A., Kirkman, G. A., Meixner, F. X., Andreae, M. O., and Gomes, B. M.: Biogenic NO emissions from forest and pasture soils: Relating laboratory studies to field measurements, J. Geophys. Res., 107, 8058, doi:10.1029/2001JD000358, 2002.

van Donkelaar, A., Martin, R. V., Leaitch, W. R., Macdonald, A. M., Walker, T. W., Streets, D. G., Zhang, Q., Dunlea, E. J., Jimenez, J. L., Dibb, J. E., Huey, L. G., Weber, R., and Andreae, M. O.: Analysis of aircraft and satellite measurements from the Intercontinental Chemical Transport Experiment (INTEX-B) to quantify long-range transport of East Asian sulfur to Canada, Atmos. Chem. Phys., 8, 2999-3014, doi:10.5194/acp-8-2999-2008, 2008.
Wang, Y., Jacob, D. J., and Logan, J. A.: Global simulation of tropospheric $\mathrm{O}_{3}-\mathrm{NO}_{\mathrm{x}}$-hydrocarbon chemistry: 1. Model formulation, J. Geophys. Res., 103, 10713-10725, 1998.

Wang, Y. X., McElroy, M. B., Martin, R. V., Streets, D. G., Zhang, Q., and $\mathrm{Fu}, \mathrm{T} . \mathrm{M} .:$ Seasonal variability of $\mathrm{NO}_{\mathrm{x}}$ emissions over east China constrained by satellite observations: Implications for combustion and microbial sources, J. Geophys. Res., 112, D06301, doi:10.1029/2006JD007538, 2007.

Williams, E. J. and Fehsenfeld, F. C.: Measurement of nitrogen oxide emissions at three North American ecosystems, J. Geophys. Res., 96, 1033-1042, 1991.

Williams, E. J., Parrish, D. D., and Fehsenfeld, F. C.: Determination of Nitrogen Oxide Emissions From Soils: Results From a Grassland Site in Colorado, United States, J. Geophys. Res., 92, 2173-2179, 1987.

Yan, X., Ohara, T., and Akimoto, H.: Statistical modeling of global soil $\mathrm{NO}_{\mathrm{x}}$ emissions, Global Biogeochem. Cy., 19, GB3019, doi:10.1029/2004GB002276, 2005.

Yang, W. X. and Meixner, F. X.: Gaseous nitrogen emissions from grasslands, CAB Int., Wallingford, UK, 67-71, 1997.

Yienger, J. J. and Levy II, H.: Empirical model of global soilbiogenic $\mathrm{NO}_{\mathrm{x}}$ emissions, J. Geophys. Res., 100, 11447-11464, 1995.

Zhang, Q., Streets, D. G., He, K., Wang, Y., Richter, A., Burrows, J. P., Uno, I., Jang, C. J., Chen, D., Yao, Z., and Lei, Y.: $\mathrm{NO}_{\mathrm{x}}$ emission trends for China, 1995-2004: The view from the ground and the view from space, J. Geophys. Res., 112, D22306, doi:10.1029/2007JD008684, 2007.

Zhang, X., Friedl, M. A., and Schaaf, C. B.: Global vegetation phenology from Moderate Resolution Imaging Spectroradiometer (MODIS): Evaluation of global patterns and comparison with in situ measurements, J. Geophys. Res., 111, G04017, doi:10.1029/2006JG000217, 2006.

Zhao, C. and Wang, Y. H.: Assimilated inversion of $\mathrm{NO}_{\mathrm{x}}$ emissions over east Asia using $\mathrm{OMI} \mathrm{NO}_{2}$ column measurements, Geophys. Res. Lett., 36, L06805, doi:10.1029/2008GL037123, 2009. 